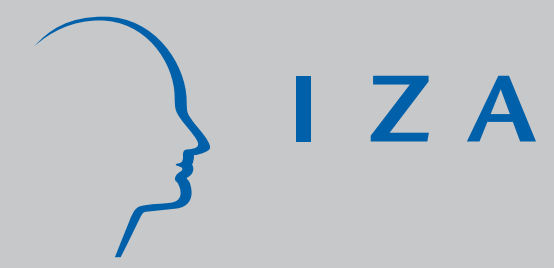

IZA DP No. 98

Industry Wage Differentials Revisited:

A Longitudinal Comparison of Germany and USA (1984-1996)

J ohn P. Haisken-DeNew

Christoph M. Schmidt

December 1999 


\title{
Industry Wage Differentials Revisited: A Longitudinal Comparison of Germany and USA (1984-1996)
}

\author{
John P. Haisken-DeNew \\ German Institute for Economic Research (DIW-Berlin) and IZA, Bonn \\ Christoph M. Schmidt \\ University of Heidelberg, CEPR, London and IZA, Bonn
}

Discussion Paper No. 98
December 1999

IZA

P.O. Box 7240

D-53072 Bonn

Germany

Tel.: +49-228-3894-0

Fax: +49-228-3894-210

Email: iza@iza.org

This Discussion Paper is issued within the framework of IZA's research areas The Future of Work and General Labor Economics. Any opinions expressed here are those of the author(s) and not those of the institute. Research disseminated by IZA may include views on policy, but the institute itself takes no institutional policy positions.

The Institute for the Study of Labor (IZA) in Bonn is a local and virtual international research center and a place of communication between science, politics and business. IZA is an independent, nonprofit limited liability company (Gesellschaft mit beschränkter Haftung) supported by the Deutsche Post AG. The center is associated with the University of Bonn and offers a stimulating research environment through its research networks, research support, and visitors and doctoral programs. IZA engages in (i) original and internationally competitive research in all fields of labor economics, (ii) development of policy concepts, and (iii) dissemination of research results and concepts to the interested public. The current research program deals with (1) mobility and flexibility of labor markets, (2) internationalization of labor markets and European integration, (3) the welfare state and labor markets, (4) labor markets in transition, (5) the future of work, (6) project evaluation and (7) general labor economics.

IZA Discussion Papers often represent preliminary work and are circulated to encourage discussion. Citation of such a paper should account for its provisional character. 
IZA Discussion Paper No. 98

December 1999

\section{ABSTRACT}

\section{Industry Wage Differentials Revisited: A Longitudinal Comparison of Germany and USA (1984-1996)}

In this paper, the inter-industry wage structure in West Germany and USA is compared using the German Socio-Economic Panel (GSOEP), the German Mikrozensus (MZ), the American Panel Study of Income Dynamics (PSID) and the American Current Population Survey (CPS) from 1984 to 1996. Using a sample of prime age full-time employed males from the respective datasets, it is shown that the structure of wages has remained remarkably stable over this time period, and that the German structure resembles the American structure strongly. Cross-sectional and panel results are provided for both countries. Controlling for unobserved heterogeneity in the random effects panel estimations reduces the industry wage dispersion by about half. Thus, although the MZ and the CPS provide very large sample sizes, panel data sets (although typically smaller in sample size) are still very important in getting at the essence of the industry wage structure and the absolute level of industry wage dispersion. In calculating inter-industry wage differentials as deviations from a hypothetical employment-share weighted mean, we use the methodology as described in Haisken-DeNew and Schmidt (1997) of calculating exact differentials and their respective standard errors.

JEL Classification: C20, J31

Keywords: Inter-Industry Wage Differentials, West Germany, USA, dummy variables, restricted least squares, weighted standard deviation

John P. Haisken-DeNew

The German Institute for

Economic Research (DIW-Berlin)

Königin-Luise-Str. 5

D-14195 Berlin

Germany

Tel.: 49-30-89789-461

Fax: 49-30-89789-109

Email: jhaiskendenew@diw-berlin.de

\footnotetext{
* This paper celebrates Jascha Pieter Haisken-DeNew, born September 1, 1997 in Berlin, Germany. The authors wish to thank Tom Crossley, Ira Gang, Franque Grimard, Dan Hamermesh, Peter Kuhn, Thomas Lemieux, Dave Richardson, Chuck Romeo, Bernhard Schimpl-Neimanns, Michael Veall, Frank Vella, Lars Vilhuber and numerous other seminar participants at McGill U (Montreal), McMaster $\mathrm{U}$ (Hamilton), Rutgers $U$ (NJ), Syracuse $U$ and York $U$ (Toronto) for their valuable suggestions and comments, while Haisken-DeNew was visiting Syracuse University from Oct 1, 1997 to Mar 31, 1998.
} 


\section{Background}

Rising inequality has been the major theme in all studies of the US-wage structure (e.g. MURPHY AND WELCH, 1992). Whereas the changes in the wage structure were dominated by supply shifts in the 1970s, associated with the entry of the baby boom generation into the labor market and with the substantial increase in the education of the young US work force, the 1980s witnessed a widening inequality both across skill groups and within narrowly defined groups of workers. The interpretation of these changes dominating the labor literature is an explanation in terms of skill-biased technological change within industries. As an alternative industry-wide shift in labor demand might have favored workers in industries with higher skill content of employment. On the other side of the Atlantic, unemployment, rather than wage inequality, is the major problem of the day. Since unemployment seems to hit unskilled European workers more severely, these patterns suggest that similar underlying forces as in the US - increasing demand for new labor - combined with more rigid wage structures and complex networks of minimum wages, shape European labor markets. Yet, little is known on how the wage structures on both sides of the Atlantic compare in detail at any point in time and intertemporally. In particular, do we observe the inter-industrial wage structure to fluctuate substantially over time within economies and do we see convergence of inter-industry wage differentials across markets ?

There has been considerable attention recently in the inter-industry wage literature to international comparisons (for example, see KAHN 1997). In this paper, the inter-industry wage structure in West Germany and USA is compared using the German Socio-Economic Panel (GSOEP), the German Mikrozensus (MZ), the American Panel Study of Income Dynamics (PSID) and the American Current Population Survey (CPS) from 1984 to 1996. Using a sample of prime age full-time employed males from the two large sample cross-sectional datasets (MZ and CPS) and the two smaller panel datasets (GSOEP and PSID) we can obtain a clear picture of what has been going on in the last 13 years. The yearly samples of the panels are still large enough to compare longitudinally as well.

Specifically, has the very segmented and homogeneous West German labor market evolved over the last 13 years, and moved closer to the American structure? Was the structure similar in both countries over the 13 year period?

\section{Inter-Industry Wage Differentials}

Often in the past, those estimating earnings functions have included industry affiliation dummies as explanatory variables, in a sort of "fixed effect" manner. Dummies were included, just for "completeness", but not with the intention of being interpreted especially. Whether industry wage differentials exhibited persistence over time, or were merely responses to random demand shocks, seemed to be a secondary issue.

If "competitive" wage models were to prevail, then clearly any industry wage differentials persisting over time would have to negligible. If in a perfectly competitive labor market, employees are 
compensated according to their opportunity cost, there can be, by definition, no room for additional wage premiums due to industry affiliation. Firms will pay enough to cover the opportunity cost to the employee, but no more, thus maximizing profits.

In response to apparent empirically observed persistent industry wage differentials, an entire literature of "efficiency" wage theories developed. Thus, firms could pay "higher-than-normal" wages for a variety of reasons, and still be at an optimal wage level. These differences would depend on employer characteristics as opposed to employee characteristics, as in the competitive model, with wage equaling marginal productivity.

KrUeger AND Summers (1988) have established themselves as the cornerstone of the interindustry wage differential literature. They outline various efficiency wage theories in explaining wage differentials for equally skilled workers, while emphasizing the role of industry affiliation in explaining these differentials. They outline four distinct "efficiency" wage arguments for paying "noncompetitive" wages. Employees are paid an additional amount over and above marginal productivity in order to avoid "turnover". The employees perceive this, and should they think of changing firms or industries, the additional amount, that they receive to stay in their current jobs, remains convincing enough that they stay. Turnover costs to the firm can be substantial. High "head-hunter" and interviewing fees, losses in production and efficiency are all turnover cost components which can be avoided if additional premiums are paid. Employees receiving wage premiums are also thought to increase their effort levels. In the competitive model, workers being paid their marginal productivity have little incentive to perform well. Losing a job would be costless, as the employee could always switch into another without loss. However, losing the job with a premium, increases the cost to the employee, thus providing the incentive for good employee performance.

Further, in firms where additional profits are shared with employees, employee feelings of loyalty are enhanced, it is argued. Such loyalty would then have an effect on productivity. When additional positions become available, there can also be substantial advantages for firms to pay wage premiums to attract a "better" employee. Hence, knowing that wage premiums are offered, the better job candidates would be attracted automatically, also raising productivity. Krueger and Summers (1988) note that heterogeneity between firms and industries is exhibited in the extent to which the firm's are able to pay (or not) these monitoring, turnover, and employee quality measuring costs.

GibBons And KATZ (1992) find evidence for the role of unmeasured ability in explaining interindustry wage differentials. If it is assumed that observable indicators of human capital sort individuals into industries reflecting a corresponding wage premium, then similarly, unobserved aspects of human capital will do the same. If "matching" plays a factor, i.e. those workers learning of the positive market valuation of their skills and abilities tending to move into jobs offering better wages and better conditions (and vice versa), for endogenous industry switchers, they conclude that the self-selection bias will strongly affect wage differential calculation. For exogenous plant closings they compare wages of workers who found new employment in other higher paying industries, and those who found new employment in other firms in the same industry. Those finding employment in other higher-paying 
industries experienced higher wages than those remaining within the industry, albeit in another firm, although industry-specific capital was not lost due to the exogenous industry switch.

DiCKEns AND KATZ (1987) cite average years of education in an industry, firm profits, larger than average firm size, and high capital-to-labor ratios, as being positively related to wages. SCHMIDT AND ZimmermanN (1991) examine the following hypotheses for the German situation in their study of wage differentials. They suggest that larger firms tend to be more innovative, and have higher capital/labor ratios. Thus, such larger firms would require higher qualified labor with more specialized skills than smaller firms. With firm-specific skills, a lower turn-over rate is attractive for both employer and employee, while still allowing workers to move laterally to other divisions of the same firm.

It is postulated that larger firms have higher profits, and that unionized labor in those firms would also benefit from the higher profits. As collective bargaining is typically organized at or near the industry level, the individual effects of industry affiliation are also of interest.

With apparently much lower observed inter-industry wage differentials in Germany, as compared to the US, DENEw AND SCHMidt (1994) stress the relative importance of human capital considerations in a highly segmented blue/white collar labor market. Thus inter-industry wage differentials might rather reflect the "composition" of white-to-blue collar jobs in the respective industries, as opposed to "efficiency wage" arguments. DeNew And Schmidt (1994) also question the portability of the American result to the German situation that industry differentials persist over time. Analyzing the employment shares of the respective industries and their varying wage differentials over time, suggests that temporary labor demand shocks may explain much of the observed wage differentials. However, the dataset used, the German General Population Survey for the Social Sciences (ALLBUS), suffers from 2 drawbacks (in hindsight): (a) yearly sample sizes are small and (b) only net monthly income is available. As demonstrated in Haisken-DeNew, Schmidt, Wagner And Biewen (1997) using GSOEP data, the difference in industry wage dispersion comparing different measures of wage/salary can be striking: using (last month's) net monthly wages compared to average hourly gross wages including all extras and benefits will produce roughly half the dispersion! Thus any results using the $A L L B U S$ tend to underestimate the dispersion and due to the small sample sizes, produce higher than warranted inter-temporal fluctuations. HAisken-DeNew (1996) examines the German wage structure using the GSOEP from 1984 to 1992 in a panel context. Here, a very stable and persistent wage structure is evident. Further there is strong evidence for the important role of unobserved heterogeneity found in the panel models.

KAHN (1997) explicitly examines the relationship between wage bargaining and industry wage levels using data from Germany, Norway, USA, Britain, Sweden and Austria and quantile regression. He finds that union wage effects are higher at the lower end of the wage distribution for the US.

GitTleman And WolfF (1993) compare 14 OECD countries using macro data and are thus unable to control for standard human capital and job characteristic explanations. They claim that these controls will not alter the differential "rankings" of the industries ${ }^{1}$. There are however no standard errors reported in the point estimates used. Without controls, the dispersion of the differentials is huge 
compared to the literature using micro data. Further, all differentials are not weighted by industry share, making international comparison more difficult, as the industry shares between countries will vary.

\section{Restricted Least Squares}

HAisken-DeNew AND SChmidt (1997) summarize the previous restricted least squares literature and suggest a two-step equivalent as a technique for wage differential analysis ${ }^{2}$. A new method of taking the estimated coefficients and the variance-covariance matrix from a first step linear model analysis, and then tranforming them in some appropriate manner in a second step to arrive at the same RLS results is rather convenient. A random effects, fixed effects, pseudo panel etc. could be run, the results transformed, and then presented in a RLS framework.

To achieve this, one can think of the new $\beta_{i}^{*}$ 's just being linear transformations of the original $\beta_{i}$ 's. The standard error of a linear transformation of the $\beta$ 's is documented, for example, in GREENE (1993). In our case, the variance-covariance matrix of the $K-1$ industry dummies is $V C\left(\beta_{i}\right)_{[K-1 \times K-1]}$, which is weighted by a combination of the average industry shares $\bar{I}_{i}$. For a single industry, say $I_{1}$, the transformation is:

$$
\begin{aligned}
V C_{K-1}\left(\beta_{i}^{*}\right) & =w * V C\left(\beta_{i}\right) * w^{\prime} \\
w & =\left[\begin{array}{lllll}
1-\bar{I}_{1}, & -\bar{I}_{2}, & -\bar{I}_{3}, & \cdots & -\bar{I}_{K-1}
\end{array}\right]
\end{aligned}
$$

and then in the more general $[\mathrm{K} \times \mathrm{K}]$ case, the weighting matrix is defined to be:

$$
W=\left[\begin{array}{ccccc}
1-\bar{I}_{1}, & -\bar{I}_{2}, & -\bar{I}_{3}, & \cdots, & -\bar{I}_{K} \\
-\bar{I}_{1}, & 1-\bar{I}_{2}, & -\bar{I}_{3}, & \cdots, & -\bar{I}_{K} \\
-\bar{I}_{1}, & -\bar{I}_{2}, & 1-\bar{I}_{3}, & \cdots, & -\bar{I}_{K} \\
\vdots & \vdots & \vdots & \ddots & \vdots \\
-\bar{I}_{1}, & -\bar{I}_{2}, & -\bar{I}_{3}, & \cdots, & 1-\bar{I}_{K}
\end{array}\right]
$$

Thus in this notation, the $[\mathrm{K}-1 \times 1] \beta_{i}$ 's can be transformed into the now $[\mathrm{K} \times 1]$ vector $\beta_{i}^{*}$ 's:

$$
\beta_{i}^{*}=W *\left[\begin{array}{c}
\beta_{1} \\
\beta_{2} \\
\vdots \\
\beta_{k-1} \\
0
\end{array}\right]
$$

and similarly the $V C\left(\beta_{i}^{*}\right)$ can be derived from the variance-covariance matrix $V C\left(\beta_{i}\right)$ coming out of the regression as follows:

$$
V C\left(\beta_{i}^{*}\right)=W * V C * W^{\prime}
$$


where

$$
V C=\left[\begin{array}{cc}
V C\left(\beta_{i}\right) & 0 \\
0 & 0
\end{array}\right] .
$$

For an implementation using the LIMDEP statistical package, see HAISKEN-DENEW (1996).

With the transformation, both the $\beta^{*}$ 's and the standard errors are independent of the base industry choice, which is in end effect what is desired. Along with the other coefficients' standard errors, the base industry's standard error is calculated using the linear combination of the standard errors of the $\beta$ 's actually used in its construction.

HAisken-DeNew AND SCHMidt (1997) suggest an improved weighted overall standard deviation of the differentials. Using the special matrix operator $\operatorname{vecd}(a)$, referring to a diagonal matrix with the column vector " $a$ " injected into the diagonal and operator $\operatorname{diag}(A)$ referring to the column vector taken from the diagonal elements of a square matrix $A$ :

$$
\sigma_{\beta^{*}}=\sqrt{\bar{I}_{i}^{\prime} \cdot \operatorname{vecd}\left(\beta^{*}\right) \cdot \beta^{*}-\bar{I}_{i}^{\prime} \cdot \operatorname{diag}\left(V C\left(\beta^{*}\right)\right)}
$$

\section{The Data}

\section{A. Choosing a Common Sample for International Comparison}

To appropriately compare several datasets from different countries it is sometimes difficult to define a common sample due to particularities of the national labor markets and institutions. Here the emphasis will be on calculating inter-industry wage differentials for prime-age (25-60) full-time working males. By picking the age groups 25-60 one hopes to avoid "education in progress" on the hand and problems due to those looking to go into retirement on the other. In Germany, there is a mandatory military or "community" service which depending on the cohort, could have lasted anywhere from 10 to 24 months. University students finish their undergraduate degrees often by 25 , but many standard "on time" students require longer. (University tuition in Germany is essentially free.) On the other hand, many apprenticeship oriented students are on the job market after the 10th grade. Germany has also been rather generous in the last decade with respect to early retirement with those in their early 60's, as a way of pushing earlier cohorts into the job market.

German females empirically tend to behave typically very different from American females, and often stay at home to raise children, withdrawing from the labor market (at least for the medium run). The German system provides relatively generous subsidies to child rearing: DM 600/month (for the first 6 months, and thereafter means-tested) for "child rearing support" Erziehungsgeld, child allowance (Kindergeld) with DM 200/child (1-2 kids), DM 300 (3rd kid) and DM 350 for the 4th and over kid). Krueger and Summers (1988) present CPS results for males and females combined, without examining a labor market participation function for females. This inflates the overall measure of wage dispersion artificially, and thus only males will be examined here, working in dependent employment, 
i.e. blue collar or white collar workers. To comply with most studies in the literature, those working in the public sector and in agriculture were dropped from the analysis. Further, for USA only whites are used in the regressions and for Germany only German nationals were used. All wage variables are hourly wages.

\section{B. The German Socio-Economic Panel (GSOEP)}

The GSOEP is panel dataset from 1984 to the present consisting of some 13,500 individuals and roughly 7,000 households living in West Germany (the "old" states) and East Germany (the "new states"). Foreigners and recent migrants are also included in the sample. Individuals from 1984 to 1996 have been closely followed. The German version of the GSOEP data is used here, although the same analysis can be made with the international "public use" version, albeit with approximately $5 \%$ fewer observations. See Haisken-DeNew AND Frick (1997) for extensive documentation on the GSOEP and Wagner, Burkhauser And Behringer (1991) for more details on the "public use" version.

For this analysis, West German males aged 25 to 60, having worked up to 80 hours per week were selected. The GSOEP uses a quasi 2-digit industry classification scheme modeled after the macrolevel official statistics from the German Statistical Office. Due to cell-size considerations and keeping in mind the wage-bargaining mechanisms in Germany, those industries that "collectively bargain together" are more or less also grouped together in the analysis as shown in Table 1. For more discussion on appropriate grouping, see DeNew AND Schmidt (1994) and HAISkEn-DeNew (1996).

The sample used from the GSOEP data was all west German males full-time employed living in west Germany. ${ }^{3}$ The GSOEP asks very detailed income information of all adult respondents directly, including gross and net monthly income (uncensored), and various other components. For more detailed information see the GSOEP-PSID Equivalent documentation in BURKHAUsER, ButRICA AND DALY (1997). The GSOEP differentiates also between actual and contractual hours worked per week. In this analysis, the maximum of the two is used. This avoids undercounting the nominal 40hour manager/salaried jobs on the top end, and on the bottom end, where a full time employed person actually only worked say 10 hours that interview week due to sickness, but would normally work 40 . The yearly samples for the 13 year period range from 700 to more than 1000. In total for the panel analysis more than 11000 person-year obervations are available, based on more than 2300 persons. As the data span more than a decade, all wage information has been deflated by the OECD main economic indicators consumer price index (base year 1990), relevant in the panel or pooled analysis. Control variables include: 3 geographical, 3 age, marital status, 5 job, and job status dummies, with

education entering as a continuous variable. For the pooled and panel analyses, year dummies are also included ${ }^{4}$ 
The Mikrozensus (MZ) is a $1 \%$ representative sample of the German population and is the counterpart to the internationally well known American CPS. As it is run by the German Federal Statistical Office (and also the respective state Statistical Offices), respondents are required by law to answer most questions put to them concerning labor market participation and demographic background. The Statistical office however has recoded all household and person identifiers from year to year to restrict any unauthorized re-indentication. Unfortunately, this also by defintion disallows any panel analysis. See Alba ET AL (1994) for more information on the Mikrozensus.

Recently an anonymized 70\% sample of the $1995 \mathrm{MZ}$ has been made available for the mere media costs from the Statistical Office as a pilot project, with the thought of making other years available in a similar manner. ${ }^{5}$ The MZ analysis presented in this paper is not only based on the "scientific-use file" $70 \%$ sample of the MZ95 but also uses the MZ89, MZ91, MZ93 waves ${ }^{6}$. Earlier waves of the available anonymized MZ do not have sufficiently detailed information in a number of variables to be able to include them. All MZ samples used here were defined to be German males living in West Germany, either blue or white collar workers, having valid income, industry education and employment status information, and aged 25 to 60 working full-time. To comply with most studies in the literature, those working in the public sector and in agriculture were dropped from the analysis. The final yearly sample sizes for the (70\% scientific use) MZ datasets were between approximately 51,000 and 56,000.

The MZ95, as do all other MZ datasets, has only a grouped income variable for the individual and this is only "net income", including all other non-labor sources. The first issue of a grouped dependent variable is in fact not nearly as problematic as it appears. As there are relatively many categories (18) and the categories themselves are relatively narrow, there is not much information loss. Thus, all income categories have been recoded to their specific category mean, and all resulting regression are simple OLS/RLS. This may seem like a strong assumption, but in fact it is not. Using the GSOEP data with actual continuous wage information, similar wage categories were simulated. Using the LIMDEP "grouped data" estimator", a standard wage equation was run, and its results were compared to the usual OLS case, and the OLS case with the wage variable recoded for the mean categorical values. All three models delivered strikingly similar coefficients and standard errors (with differences typically being several decimal places over). Thus, we have chosen to "approximate" and use the "pseudo-continuous" wage variable recoded for the categorical means in all of our regression analyses. Control variables include: 3 geographical, 3 age, marital status, 10 job, job status and 6 educational dummies.

\section{The American Panel Study of Income Dynamics (PSID)}

The PSID can be thought of the grandad of current panel studies available: the German SOEP, the British HPS, the Dutch SOEP to name a few. Started in 1968 the PSID originally contained 5000 households. The PSID today is available from the University of Michigan ${ }^{8}$ with complete datasets 
up to 1992. More recent datasets are available provisionally, however most important labor market variables relevant for this analysis are currently missing. The PSID consists of proxy interviews for all individuals in the household except for the household head who is the respondent. Most labor market related questions are directed to the head (almost always male) or his spouse. Thus working age sons and daughters living at home under their parents roof are not asked any detailed labor market questions $^{9}$. Therefore the data used ${ }^{10}$ are effectively from the respective household heads. See HiLL (1992) for a more detailed introduction to the PSID and for the GSOEP-PSID Equivalent file see Burkhauser, Butrica and Daly (1997).

The income information in the PSID is collected for hourly wage workers and salary workers, however the amounts are directly translated into an hourly figure, top-coded at \$99.98. (Only 4 observations from 9844 are top-coded. Each yearly sample is more than 1000.) The sample is selected as follows: all males working at least 25 hours per week but not more than 80 are included. As there is no "full time" or "part-time" variable in the PSID, only private, non-government workers (dependent employed) who are currently working or temporarily not (due to illness or holidays etc) are taken. As the data span almost a decade, all wage information has been deflated by the OECD main economic indicators consumer price index (base year 1990), relevant in the panel or pooled analysis. Control variables include: union status ${ }^{11}$, marital status, 4 job, 3 educational, 3 age, and 3 geographical dummies. For the pooled and panel analyses, year dummies are also included.

\section{E. The American Current Population Survey (CPS)}

The CPS is a series of repeated cross-sections collected by the US Bureau of Labor each month consisting of approximately 60,000 households. An adult (the reference person) in each household provides proxy interviews for all adult household members. FEEnBERG (1997) describes the sample "rotation" idea: "Each household entering the CPS is administered 4 monthly interviews, then ignored for 8 months, then interviewed again for 4 more months. If the occupants of a dwelling unit move, they are not followed, rather the new occupants of the unit are interviewed. Since 1979 only households in months 4 and 8 have been asked their usual weekly earnings/usual weekly hours." The monthly 1984-1993 STATA data files from the NBER CPS "Labor Extracts, 2nd Edition" CDROM are used. All monthly files are merged together into yearly files ${ }^{12}$.

Males aged 25 to 60, working full and part time, having worked up to 80 hours per week were selected. The 3-digit CIC (Census Industrial Classification) schemes are used in their estimations, grouped into the 1.5-digit categories. Their control factors are: 4 age, 8 occupation, 3 region, central city, union, ever married, and veteran. The yearly samples sizes range from approximately 34,000 to 50,000 over the 13 year period. 


\section{Choosing a Common Industry Classification}

ZANCHI (1992) outlines the American and German institutional differences in industry structure, necessary for empirical comparison. Specifically, the role of unionization is emphasized, and the varying levels of bargaining. The U.S. labor market, she writes, is best described as an extremely decentralized economy, with for example in 1984, union density being only some $18 \%$ for non-agricultural blue and white collar employees. Germany however, during this same time period, in comparison to other western economies, exhibited a moderate degree of unionization at $42 \%$ of all industrial workers.

American wage bargaining occurs primarily at the firm or factory level, each firm for itself. There is typically no central bargaining body. This is in stark contrast to the German structure, where collective wage agreements are made at a collective regional and industry level, involving national trade unions and employer associations. The most important labor organization in the U.S. is the American Federation of Labor (AFL-CIO). However, it does not engage itself in any collective bargaining. As ZANCHI (1992) points out, furthermore it has never signed a labor contract. Again, the German experience is much different.

The massive union confederation Deutscher Gewerkschaftsbund (DGB), comprising of $80 \%$ of all unionized employees as SCHMIDT AND ZimmERMAnN (1991) point out, on the other hand, is subdivided into 17 branches corresponding to the various member industries. Wage bargaining in the metal industry sets the direction for all wage bargaining in other industries. The typical one-year contracts made by the powerful Industriegewerkschaft Metall (IG Metall) can truely influence wage bargaining throughout the economy.

Striking Metall workers in Bavaria in March 1995 managed to achieve a 4\% raise, even before it had developed into a drawn-out full blown strike, when throughout most of the talks, the employer association had been basically offering something close to a zero-round. This success quickly spilled over into the Chemie worker demands, in their negotiations. Weeks later Metall workers in the province of Nordrhein-Westfalen also adopted these demands, with the employer association expected to accept. Similarly, within days the same demands rippled into the Handel, Banken und Versicherung industry with similar expectations of success.

In the U.S., the rippling effect of one unions' bargaining into another industry, or firm is very low in contrast, with contracts being of a much longer duration, often 3 years. The German wage bargaining experience has been typically "cooperative", with unions and employer associations more or less settling with compromise solutions. American bargaining can be much more extreme, with all-or-nothing bargaining positions.

To best capture the individual industry wage bargaining and union power, an industrial classification scheme must incorporate these elements. DeNEw AND Schmidt (1994) propose an industrial classification geared toward that of Federal Statistics Office Statistisches Bundesamt. As the role of unions in wage setting in Germany is so much more important, this is seen as a crucial step in adequately tackling the question of wage differentials. The 10 main 1-digit industrial classifications are 
used, with the exception of the manufacturing industry, entering at the 2-digit level. As manufacturing's employment share in the economy is roughly half, and clearly the largest, it is then subdivided into its seven 2-digit components, making a total of 16 (including I-Agriculture and X-Public Service).

Table 1: Industry Classification Outline - GSOEP, MZ and CPS

\begin{tabular}{rllll}
\hline Index & Industry & GSOEP & MZ95 & CPS-CIC \\
\hline II & Energy/Mining & 3,4 & $101-112,231-233,401-410$ & $40,460-499$ \\
III.1 & Chemicals & 5 & $241-247$ & $41-50,190-209$ \\
III.2 & Plastics & 6 & $251-252$ & $180-189,210-219$ \\
III.3 & Stone/Ceramics & 7 & $120-145$ & $261-268$ \\
III.4 & Metal & $8-10$ & $271-372$ & $250-269$ \\
III.5 & Wood/Printing & 11 & $201-223$ & $270-399$ \\
III.6 & Textiles/Clothes & 12 & $171-193$ & $160-179,230-249$ \\
III.7 & Food & 13 & $151-160$ & $132-159,220-229$ \\
IV & Construction & 14,15 & $451-455$ & $100-131$ \\
V & Trade & $16-18$ & $501-527$ & $473-699$ \\
VI & Transportation & $19-21$ & $601-642$ & $400-459$ \\
VII & Banking & 22,23 & $651-672$ & $700-720$ \\
VIII & Other Services & $24-30$ & $551-555,701-748,801-853,920-930$ & $721-760,762-872,882-899$ \\
IX & Non Profit & 31,32 & $910-913,950,990$ & $761,873-881$ \\
& & & & \\
\hline
\end{tabular}


Table 2: Industry Classification Outline - GSOEP and PSID

\begin{tabular}{|c|c|c|c|}
\hline & Industry & GSOEP & PSID \\
\hline I & Agric.,Forestry & 1 & $17-27$ \\
\hline I & Fishing & 2 & 28 \\
\hline II & Energy & 3 & $377,378,467-479$ \\
\hline II & Mining & 4 & $47-57$ \\
\hline III.1 & Chemicals & 5 & $347,357-369$ \\
\hline III. 2 & Synthetics & 6 & $348,349,379-387$ \\
\hline III. 3 & Earth/Clay/Stone & 7 & $119-138$ \\
\hline III. 4 & Iron/Steel & 8 & $139-169$ \\
\hline III. 4 & Mechanical Engineering & 9 & $177-198,219-238$ \\
\hline III. 4 & Electrical Engineering & 10 & $199-209,239-259$ \\
\hline III. 5 & Wood/Paper/Printing & 11 & $107-118,328-339$ \\
\hline III. 6 & Clothing/Textiles & 12 & $307-327,388-398$ \\
\hline III. 7 & Food industry & 13 & $268-299$ \\
\hline IV & Construction & 14 & 67 \\
\hline IV & Construction Related & 15 & $68-77$ \\
\hline V & Wholesale & 16 & $507-588$ \\
\hline V & Trading Agents & 17 & - \\
\hline $\mathrm{V}$ & Retail & 18 & $607-698$ \\
\hline VI & Train system & 19 & 407 \\
\hline VI & Postal system & 20 & $447-449,907$ \\
\hline VI & Other Transport & 21 & $408-429$ \\
\hline VII & Financial Institutions & 22 & $707-709$ \\
\hline VII & Insurance & 23 & 717 \\
\hline VIII & Restaurants & 24 & 777,778 \\
\hline VIII & Service Industry & 25 & $779-809$ \\
\hline VIII & Trash Removal & 26 & - \\
\hline VIII & Education/Sport & 27 & $857-869$ \\
\hline VIII & Health Services & 28 & $828-848$ \\
\hline VIII & Legal Services & 29 & 718,849 \\
\hline VIII & Other Services & 30 & $727-759,888-897$ \\
\hline IX & Voluntary/Church & 31 & $877-887$ \\
\hline IX & Private Households & 32 & 769 \\
\hline $\mathrm{X}$ & Regional Authority & 33 & $917-937$ \\
\hline $\mathrm{X}$ & Social Security & 34 & - \\
\hline
\end{tabular}




\section{Empirical Applications}

The issues to be examined are: (a) how do the absolute levels of differentials compare across countries, i.e. does the metal industry earn a similar wage premium in German as in USA, and (b) how does the overall dispersion in Germany compare with that in USA. Tables 6-12 present the regression results for the GSOEP, PSID, MZ and CPS. A graphical representation for the cross-sectional results is given by Figures $3(\mathrm{a})-16(\mathrm{~d})$.

\section{A. Absolute Levels of Differentials}

As there are many datasets and many time periods under consideration in this study, it would be convenient to have a single summary measure to compare the American and German wage structures. An albeit crude measure of inter-country wage structure similarity is obtained by the simple correlation coefficient. Table 3 presents correlation coefficients derived from the inter-industry wage differential coefficients using a yearly pair-wise comparison of the four respective German and American datasets. An overall correlation coefficient is reported using available years, depending on the dataset (seen in the first row). The structure estimated in the Mikrozensus (MZ) seems to be very close to that of the CPS (0.89). The lowest relative amount of similarity (although absolutely still high) is found between the GSOEP and the PSID (0.70).

Looking at each industry individually, the results are shown graphically (point estimates with confidence intervals (equivalent to critical t-values set to 1.645) in Figures 3(a)-16(d). Examples of consistently positive wage differentials are found in: II-Energy/Mining, III.1-Chemicals, III.4-Metal, and VII-Banking/Insurance. Average wages are paid in III.3-Stone/Ceramics, III.5-Wood/Printing, and more or less IV-Construction. Negative wages are paid in III.6-Textiles, III.7-Food, V-Trade, VIII-Other Services, and IX-Non Profit.

III.2-Plastics and VI-Transportation seem to be the obvious differences between Germany and the United States. Plastics and Transportation are paid near average in Germany whereas in the United States the industries obtain positive differentials.

To address the possible effects of unobserved individual heterogeneity using the PSID and GSOEP panel data, a random effects panel model is used. The PSID and the GSOEP produce very similar results, with the following exceptions: VI-Transportation is positive in USA and negative in Germany, IV-Construction is average in Germany but positive in USA and III.5-Wood/Printing is average in Germany but negative in Germany.

A fixed-effect model is used as well for the GSOEP and PSID, as displayed in Tables 5 and 10 and Fig. 2(a) and Fig. 2(b). Here the differences between the two datasets increase for the industries: II-Energy and III.3-Stone, and VI-Banking becomes negative. 
Table 3: Coefficient Correlation

\begin{tabular}{ccccc}
\hline & SOEP - CPS & SOEP - PSID & MZ - PSID & MZ - CPS \\
\hline ALL & 0.7113 & 0.7018 & 0.8499 & 0.8907 \\
& & & & \\
84 & 0.7552 & 0.7359 & - & - \\
85 & 0.8325 & 0.7529 & - & - \\
86 & 0.7796 & 0.6947 & - & - \\
87 & 0.7751 & 0.6948 & - & - \\
88 & 0.8290 & 0.8187 & - & - \\
89 & 0.6923 & 0.7537 & 0.8656 & 0.9332 \\
90 & 0.6636 & 0.6707 & - & - \\
91 & 0.7501 & 0.6903 & 0.8363 & 0.9115 \\
92 & 0.5622 & 0.6085 & - & - \\
93 & 0.7647 & - & - & 0.9094 \\
94 & 0.6294 & - & - & - \\
95 & 0.6709 & - & - & 0.8092 \\
96 & 0.6390 & - & - & - \\
\hline
\end{tabular}

\section{B. Dispersion}

At the bottom in the Tables 6-12, there is a reported overall measure of industry wage dispersion. $\mathrm{S}_{\beta}^{* R A W}$ refers to the measure associated with just wage regressed on a constant and industry dummies (a so-called measure of raw differentials), whereas $\mathrm{S}_{\beta}^{* F U L L}$ refers to the dispersion associated with the full model including the above mentioned human capital variables, job characteristics, geographic indicators etc. As the tables are too numerous to report coefficients for both the RAW and FULL models, only the FULL models are reported. However the reduction of explainable dispersion is of interest here.

To address the possible effects of unobserved individual heterogeneity using the PSID and GSOEP panel data, a random effects panel model can be employed and produces some interesting results. For the GSOEP, compared to the pooled data model, the overall dispersion is reduced by about half (raw model from 0.097 to 0.037 and the full model from 0.074 to 0.045 ). Very similar results are obtained for the PSID. The full model dispersion drops from 0.128 to 0.062 and the raw model from 0.168 to 0.062 . Thus clearly large sample cross-sectional results, such as based on the CPS or MZ are over-estimating the overall dispersion, due to data design. The drop in dispersion going from a pooled data OLS estimator to a RE panel estimator is substantially larger than the drop going from a raw model to a full model. Thus panel data ${ }^{13}$ must clearly be given more attention in the industry wage differential literature.

For the GSOEP and PSID, a fixed effects panel model can also be employed. This has the drawback that explanatory variables used in the regression need to be time-varying, otherwise these variables will be collinear with the individual fixed effects or constants. Thus, a raw model is run without any additional variables (other than the industry differentials themselves and year dummies). See Tables 5 and 10 and Fig. 2(a) and Fig. 2(b). The dispersion in the GSOEP and PSID is almost identical at 4.59 and $4.98 \%$-points respectively, however compared to the random effects model, the correlation coefficient between the two datasets is much lower at 0.31 . 
Table 4: Industry Wage Dispersion Over Time (\%-pt StdDev)

(a) Total Dispersion

\begin{tabular}{ccccc}
\hline & SOEP & PSID & MZ & CPS \\
\hline 84 & 0.07377 & 0.14720 & - & 0.12701 \\
85 & 0.08839 & 0.16018 & - & 0.12757 \\
86 & 0.10134 & 0.17397 & - & 0.12742 \\
87 & 0.09614 & 0.16265 & - & 0.12095 \\
88 & 0.08186 & 0.16699 & - & 0.12012 \\
89 & 0.09131 & 0.16932 & 0.08620 & 0.12935 \\
90 & 0.09660 & 0.16771 & - & 0.12918 \\
91 & 0.09162 & 0.16530 & 0.08592 & 0.12892 \\
92 & 0.08475 & 0.16639 & - & 0.12794 \\
93 & 0.10523 & - & 0.08727 & 0.12305 \\
94 & 0.11359 & - & - & 0.11896 \\
95 & 0.10757 & - & 0.08661 & 0.11548 \\
96 & 0.11954 & - & - & 0.11584 \\
& & & & \\
\hline & \multicolumn{5}{c}{}
\end{tabular}

(b) Unexplained Dispersion

\begin{tabular}{ccccc}
\hline & SOEP & PSID & MZ & CPS \\
\hline 84 & 0.06429 & 0.11936 & - & 0.10960 \\
85 & 0.06603 & 0.11283 & - & 0.10805 \\
86 & 0.07860 & 0.14415 & - & 0.10714 \\
87 & 0.08101 & 0.13256 & - & 0.10267 \\
88 & 0.07328 & 0.12102 & - & 0.10100 \\
89 & 0.07454 & 0.12307 & 0.06366 & 0.10707 \\
90 & 0.07802 & 0.13365 & - & 0.10334 \\
91 & 0.07005 & 0.11776 & 0.06959 & 0.10210 \\
92 & 0.04575 & 0.12339 & - & 0.09945 \\
93 & 0.07923 & - & 0.06793 & 0.09730 \\
94 & 0.08285 & - & - & 0.08020 \\
95 & 0.07748 & - & 0.06915 & 0.07739 \\
96 & 0.09539 & - & - & 0.07653 \\
& & & & \\
\hline
\end{tabular}

Using the GSOEP, the overall dispersion of industry wages in Germany seems to be growing over time as seen in Table 4(b), going from 6.4\%-pts in 1984 to 9.5\%-pts in 1996. The CPS on the other hand displays a different trend for the USA, slightly reducing over time from 10.9\%-pts in 1984 to 7.6\%-pts in 1996. It is well known in the literature that the return to education has been steadily increasing in recent years in the USA, and if education is not equally distributed across industries, that this increase might account for a higher explained wage portion (and thereby reduced dispersion). (Compare the CPS results in Table 4(a) and Table 4(b); the total dispersion has not decreased that much, whereas the unexplained dispersion has to a much greater extent.) 


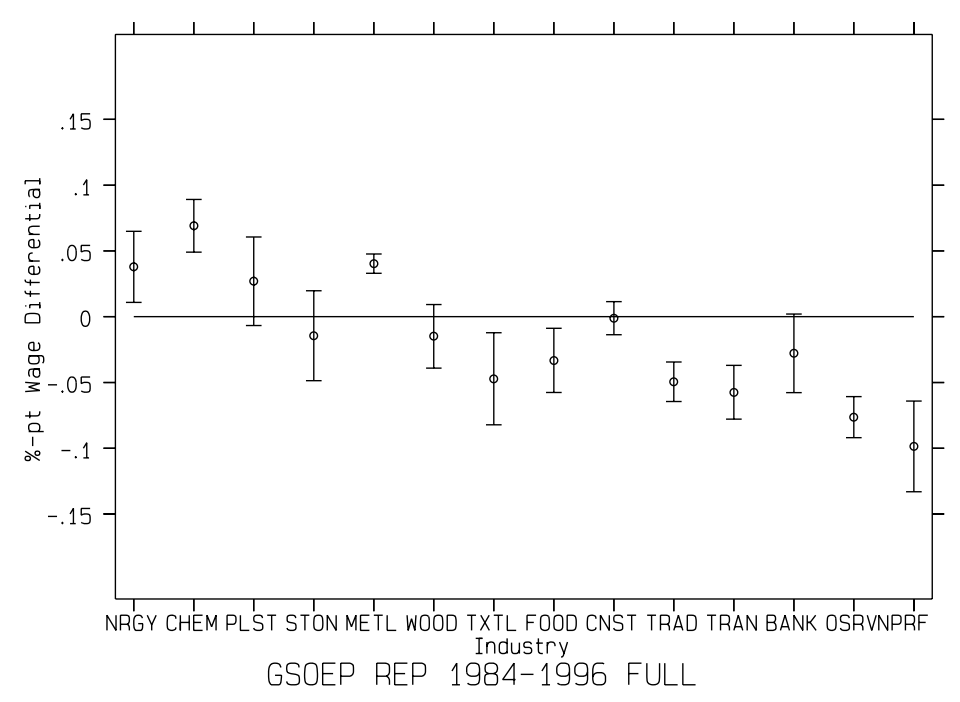

(a) Germany

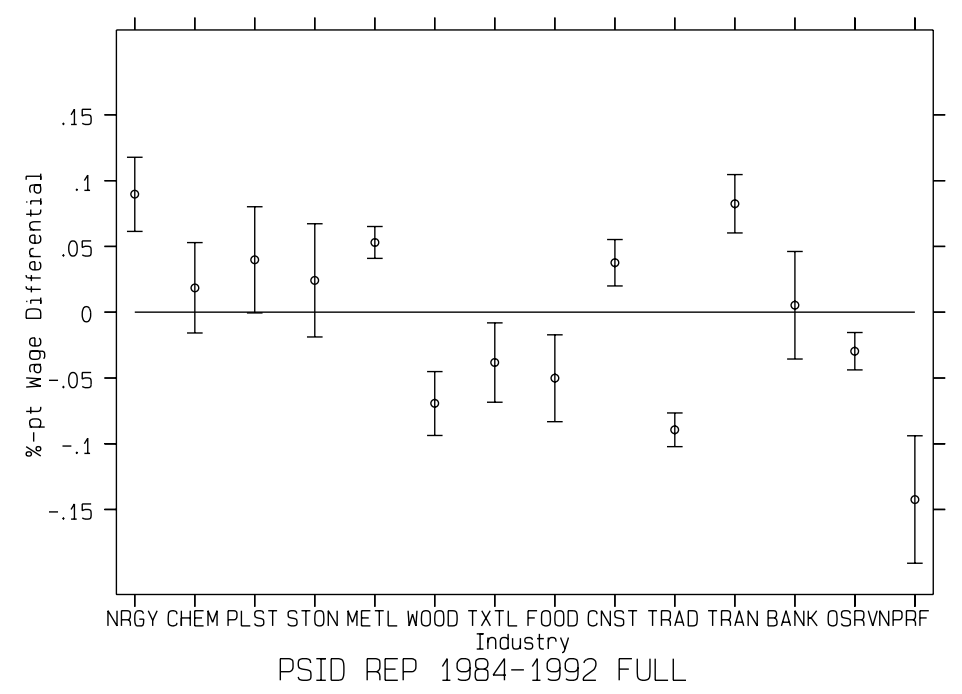

(b) U.S.A.

Figure 1: Inter-Industry Wage Differentials: RE Panel 


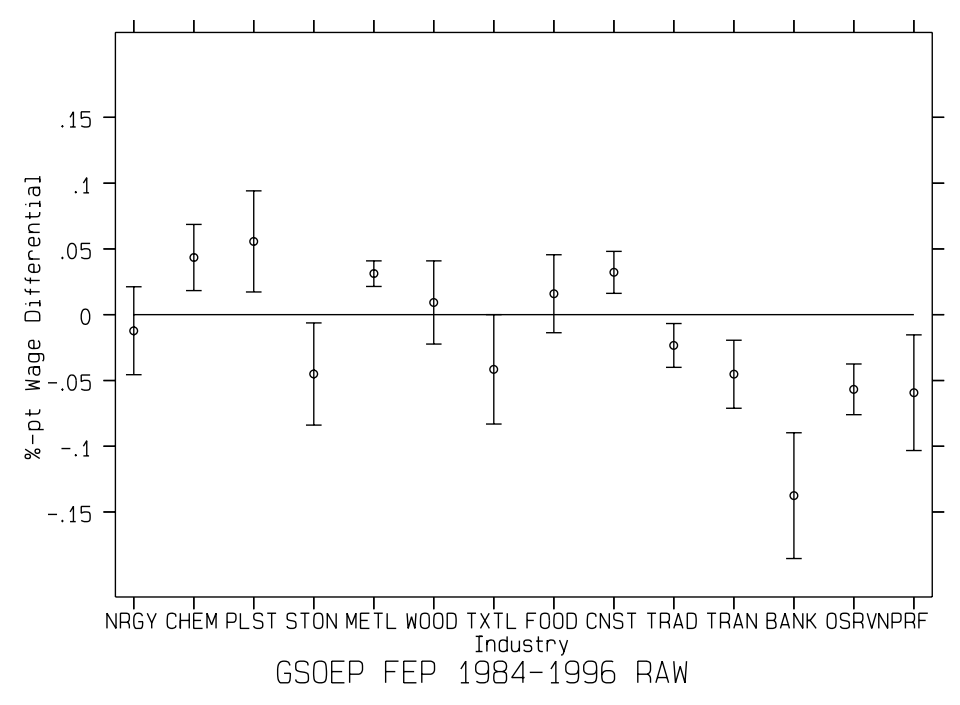

(a) Germany

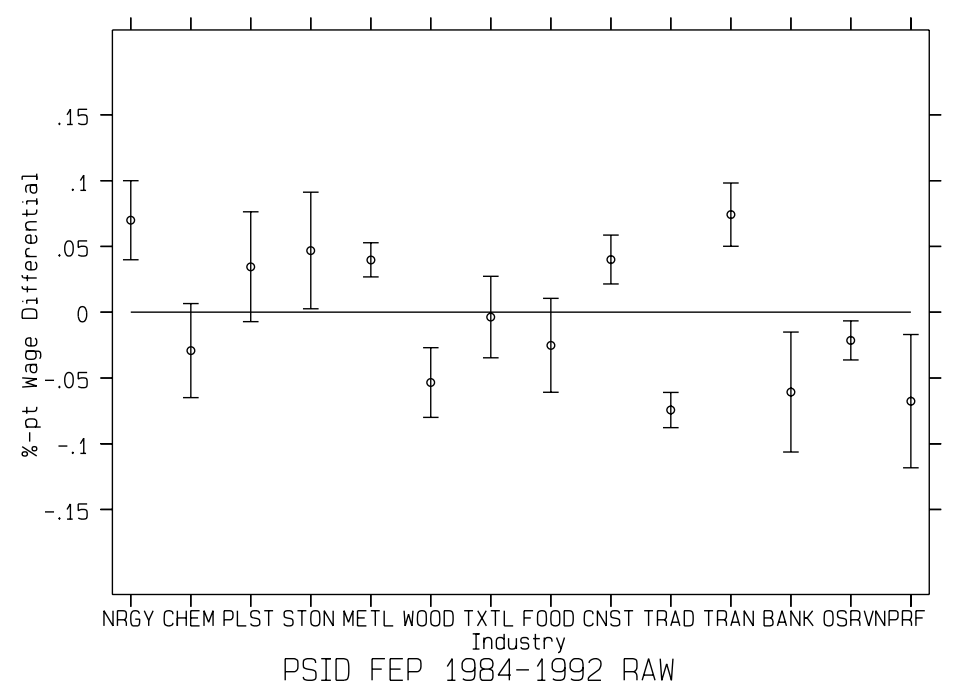

(b) U.S.A.

Figure 2: Inter-Industry Wage Differentials: FE Panel RAW 


\section{Conclusions}

Using the RLS technique outlined in HAISKEn-DENEW AND SCHMidT (1997), inter-industry wage differentials were calculated for the United States and Germany for the time period 1984-1996. For each country, both large sample cross-sectional datasets were used (CPS and MZ), as well as smaller sample panel datasets (PSID and GSOEP). Even after controlling for standard human capital components, job characteristics and status, and geographical indicators, the industrial structure of wages in Germany and the USA is shown to be substantial and very similar across the board and remarkably stable for most industries over this 13 year period. Overall correlation coefficients comparing American industry wage differentials to those of Germany are in the range of 0.7-0.9.

Although the wage dispersion using the random effects panel model (6.1\%-pts) in the USA is slightly larger than in Germany (4.5\%-pts), the differences appear to be minimal. Indeed, using the fixed effects raw model estimates the dispersion to be $4.98 \%$-pts and $4.59 \%$-pts, respectively. The panel results using the PSID and the GSOEP clearly illustrate that individual heterogeneity plays a very large role in the absolute level of wage dispersion, accounting for typically half. However, most of the previous industry wage differential literature has used only cross-sectional data. The CPS and MZ provide large sample cross-sectional evidence of similar structures in the two countries and affirm the panel results. 


\section{REFERENCES}

Alba, Richard, Walter Mueller, Bernhard Schimpl-Neimanns, "Secondary Analysis of Official Microdata", (1994), 57-78, in: Borg, Ingwer and Peter Ph. Mohler (Eds.). Trends and Perspectives in Empirical Social Research, de Gruyter, Berlin/New York.

Burkhauser, Richard V., Barbara A. Butrica, and Mary C. Daly, "The Syracuse University PSIDGSOEP Equivalent Data File: A Product of Cross-National Research." Syracuse University Cross-National Studies in Aging Program Project, Paper No. 25, (1995).

DeNew, John P. and Christoph M. Schmidt, "The Industrial Structure of German Earnings 19801990," Allgemeines Statistisches Archiv 78 (1994), 141-159.

Dickens, W.T. and L.F. Katz "Inter-Industry Wage Differences and Industry Characteristics," in K. Lang and J.S. Leonard (Eds.) Unemployment and the Structure of Labor Markets, New York, Basil Blackwell, (1987) 48-89.

Feenberg, Daniel "Documents for Use with the NBER Extracts from the CPS Merged Outgoing Rotation Groups", NBER, May (1997) mimeo.

Fitzenberger, B., C. Kurz (1997) "New Insights on Earnings Trends across Skill Groups and Industries in West Germany", University of Frankfurt/Oder, Working Paper No. 85

Gibbons, R. and L.F. Katz "Does Unmeasured Ability Explain Inter-Industry Wage Differentials ?," Review of Economic Studies 59, (1992), 515-535.

Gittleman and Wolff "International Comparisons of Inter-Industry Wage Differentials," Review of Income and Wealth, 39, 3, (1993), 295-312.

Greene, William H., "LIMDEP - An Econometric Modeling Program for the IBM PC," The American Statistician 40 (1985), 209.

Greene, William H., "Econometric Analysis, Second Edition", New York, MacMillan Publishing Company (1993)

Haisken-DeNew, John P. "Migration and the Inter-Industry Wage Structure in Germany," Springer Verlag, Heidelberg (1996).

Haisken-DeNew, John P. and Joachim R. Frick "Desktop Companion to the German Socio-Economic Panel Study (GSOEP)", German Institute for Economic Research, Berlin, unpublished manuscript (1997).

Haisken-DeNew, John P. and Christoph M. Schmidt "Inter-Industry and Inter-Region Differentials: Mechanics and Interpretation," The Review of Economics and Statistics, August (1997), 79, 3, 516-521. 
Haisken-DeNew, John P., Christoph M. Schmidt, Gert G. Wagner and Martin Biewen "What's in a Wage ? Measurement Issues in Analyzing the Wage Structure," DIW-Berlin and AWI-University of Heidelberg, mimeo (1997).

Helwege, J. and J. Wagner "More on the International Similarity of Interindustry Wage Differentials: Evidence from the Federal Republic of Germany and the United States," Federal Reserve Board: Finance and Economics (Washington, D.C.) Working Paper No. 167 (1991).

Hill, Martha "The Panel Study of Income Dynamics: A User's Guide," Sage Publications, Newbury Park (1992).

Kahn, Lawrence M. "Collective Bargaining and the Interindustry Wage Structure: International Evidence," Cornell University, School of Industrial and Labor Relations, mimeo (1997).

Krueger, Alan B. and Lawrence Summers, "Efficiency Wages and the Inter-Industry Wage Structure," Econometrica 56 (1988), 259-293.

Murphy, Kevin M., Finis Welch, "The Structure of Wages," Quarterly Journal of Economics (1992), 107, 1, 285-326.

NBER, "The CPS Labor Extracts," National Bureau of Economic Research, Cambridge, MA, USA. Foreword by Daniel Feenberg. Data on CDROM in STATA format, (1994).

NBER, "The CPS Labor Extracts, 2nd Edition," National Bureau of Economic Research, Cambridge, MA, USA. Foreword by Daniel Feenberg. Data on CDROM in STATA format, (1994).

Schmidt, C.M. and K.F. Zimmermann, "Work Characteristics, Firm Size and Wages," Review of Economics and Statistics (1991) 73, 705-710.

Wagner, Gert, Richard V. Burkhauser and Behringer, Friederike, "The English Language Public Use File of the German Socio-Economic Panel Study," The Journal of Human Resources (1993), 28, $2,429-433$.

Zanchi, L., "The Inter-Industry Wage Structure: Empirical Evidence for Germany and a Comparison with the US and Sweden," EUI (Florence) Working Paper No. 92/76 (1992). 


\section{Notes}

${ }^{1}$ Gittleman And Wolff (1993) cite Helwege and Wagner's (1991) micro analysis, who do not report standard errors, rendering inference decisions impossible, thus it is difficult to make such a generalization. Helwege And Wagner (1991) cite Krueger and Summers (1988), but make no clear mention of the exact estimation technique used, or of the question of calculating coefficient standard errors. One needs to be cautious when analyzing point estimates without respective standard errors.

${ }^{2}$ Fitzenberger And Kurz (1997) suggest a two-step RLS procedure for quantile regression

${ }^{3}$ The data were processed using the TDA distribution of the GSOEP. The data are available in ready-made Windows binary datafiles in Stata, SAS, SPSS and TDA format as well as in ASCII format. Retrieval/match files can be automatically generated using the bilingual (German/English) SOEPINFO-WWW on the SOEP Homepage http://www.diw-berlin.de/soep. This feature is available for all supported statistical packages.

${ }^{4}$ Firm size is available for the GSOEP, PSID, and MZ, but not for the CPS and for reasons of international comparability is therefore not included as a control variable in the analysis.

${ }^{5}$ The authors would like to thank the German Society for Social Science Infrastructure (GESIS), the Federal Statistical Office in Wiesbaden, the Federal Ministry of Education, Science, Research and Technology (BMBF) and more specifically Mr. Zapf, Mr. Heidenreich, and Mr. Riede for their efforts in making the MZ95 publically available.

${ }^{6}$ The results using earlier waves of the anonymized 70\%-sample data were obtained during a 4-day research visit to ZUMA-Mannheim in August 1997. We would like to thank Mr. Schimpl-Neimanns, head of the Micro-Data division and his team heartily at ZUMA for their very generous hospitality and very helpful technical support while we there and for making access to the data as user-friendly as possible.

${ }^{7}$ To simulate a semi-log regression, the actual wage breakpoints were appropriately in log form.

${ }^{8}$ See http://www. umich.edu/ psid for the PSID homepage.

${ }^{9}$ Note that in the GSOEP, all working age persons are sampled directly and asked labor market related information.

${ }^{10}$ The bulk of the data work done for the PSID was using the PSID in TDA archive format. TDA is a freeware program from Goetz Rohwer available (along with any updates) from the GSOEP homepage http://www.diw-berlin.de/soep. Many thanks to Goetz Rohwer, University of Bochum for his help in accessing the PSID data in TDA format. 
${ }^{11}$ Union status is not included in the German analysis, as union status has never been shown to make a statistical difference for males. Unions are active in almost every industry in Germany, however a it is illegal to pay union and non-union workers different wages. Furthermore, there are no "closed shops" in Germany.

${ }^{12}$ In addition to the standard "annual earnings files" aef8401.dta to aef9312.dta the more recent CPS files morg94.dta, morg95.dta and morg96.dta (merged outgoing rotation groups) were made available as early-releases on the NBER WWW server http://www.nber.org. Thanks to Daniel Feenberg at the NBER for his help in accessing the early releases.

${ }^{13}$ Krueger And Summers (1988) look at a panel matched CPS file and control for industry classification coding errors. The 1.5 German classification used here has been grouped to (comparatively) very aggregate levels, and thus the likelihood of misclassification is very small. 


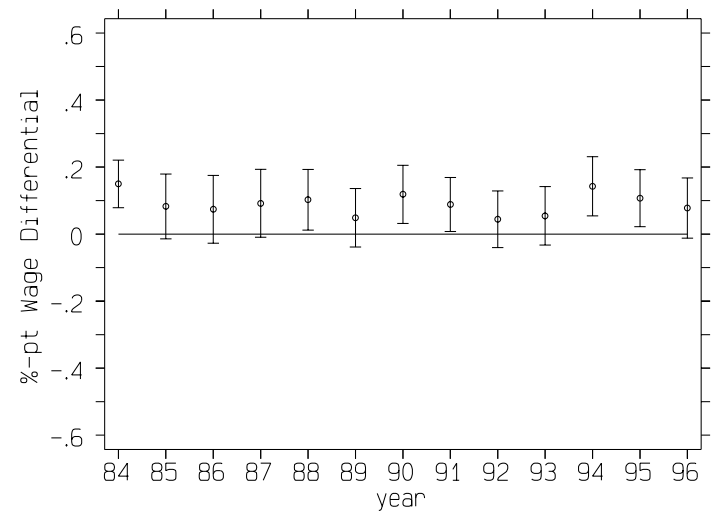

(a) GSOEP

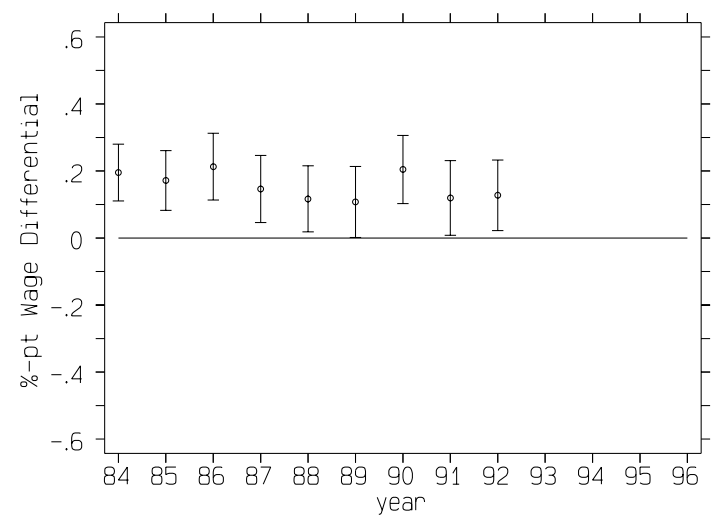

(c) PSID

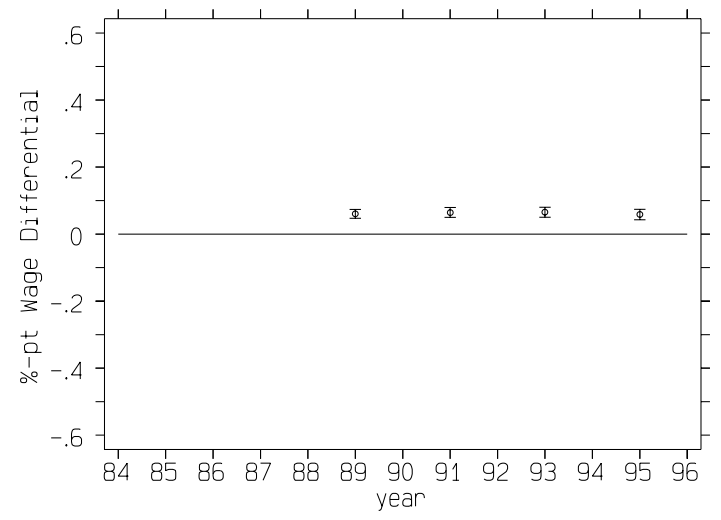

(b) Mikrozensus

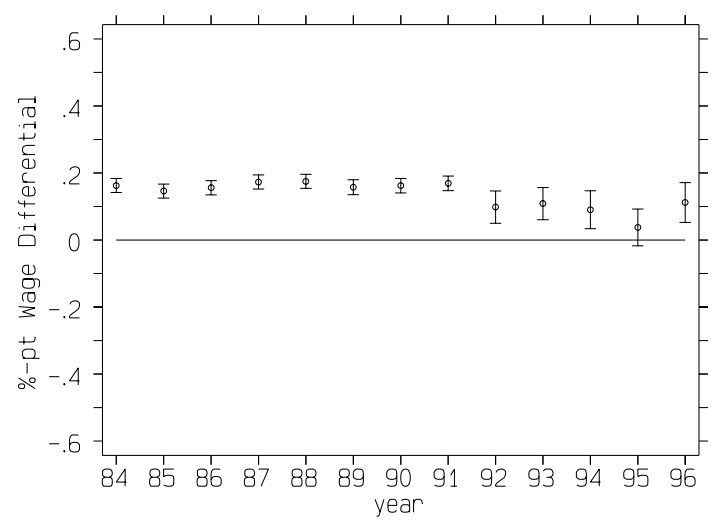

(d) CPS

Figure 3: II-Energy/Mining 


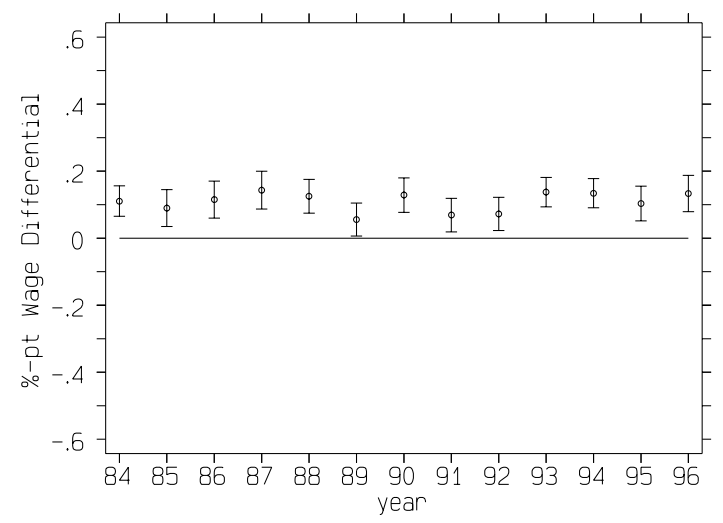

(a) GSOEP

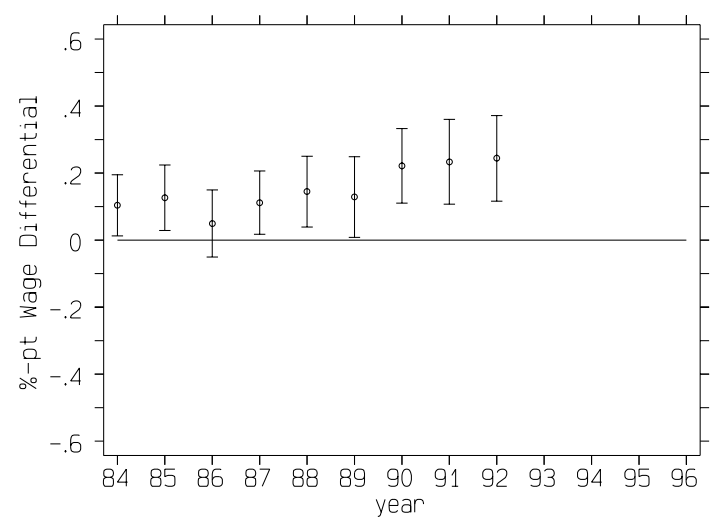

(c) PSID

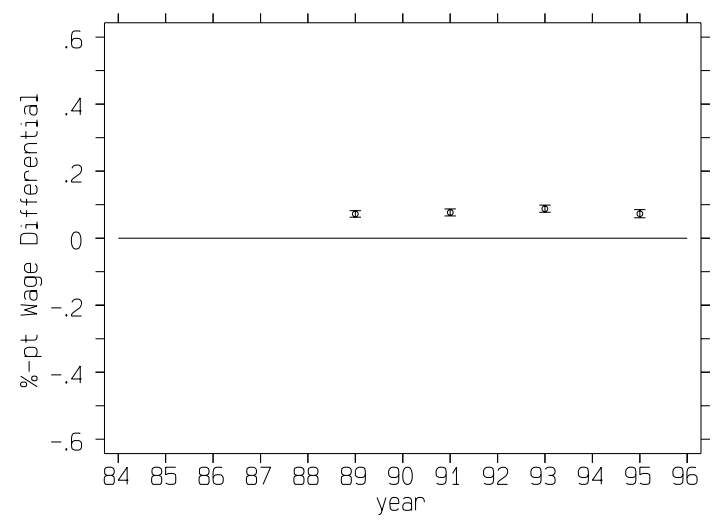

(b) Mikrozensus

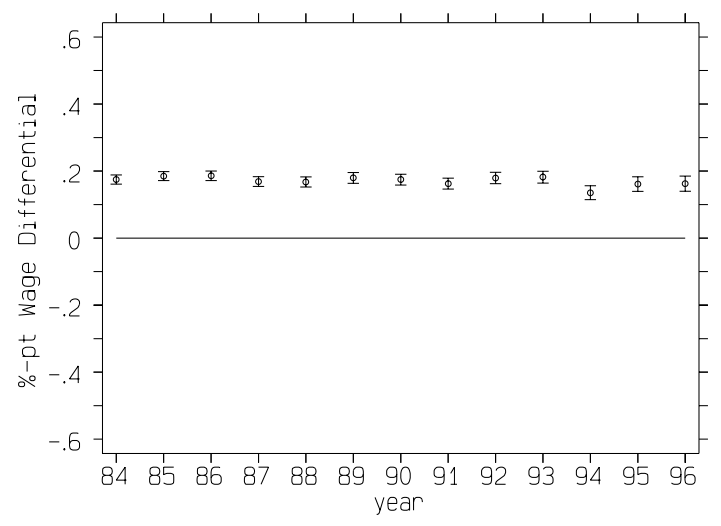

(d) CPS

Figure 4: III.1-Chemicals 


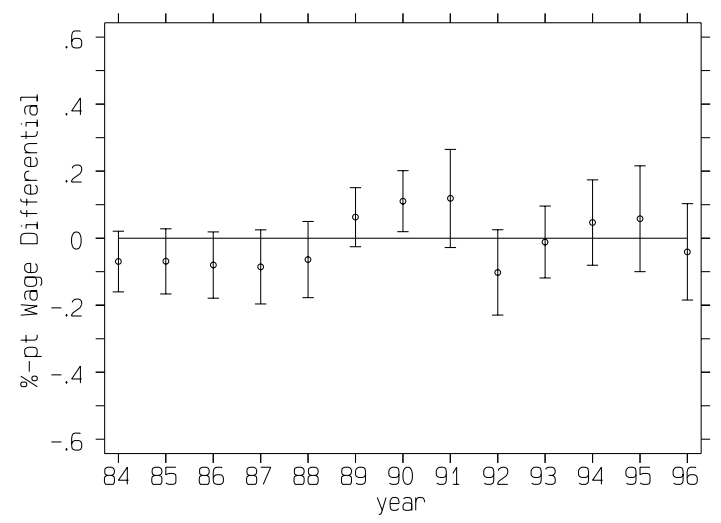

(a) GSOEP

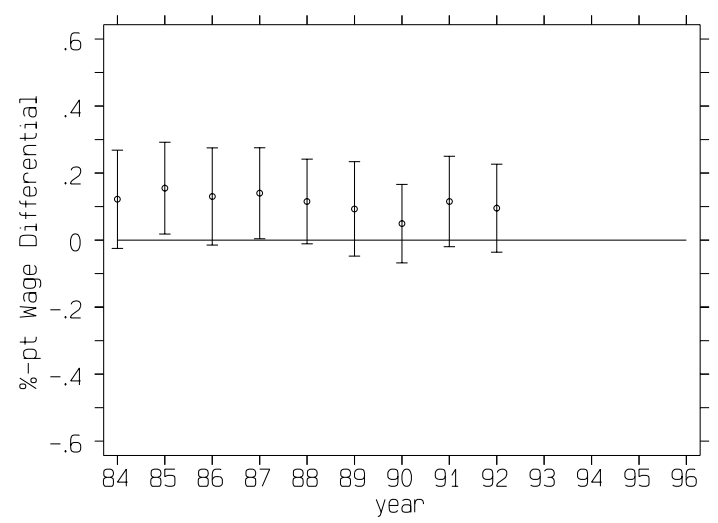

(c) PSID

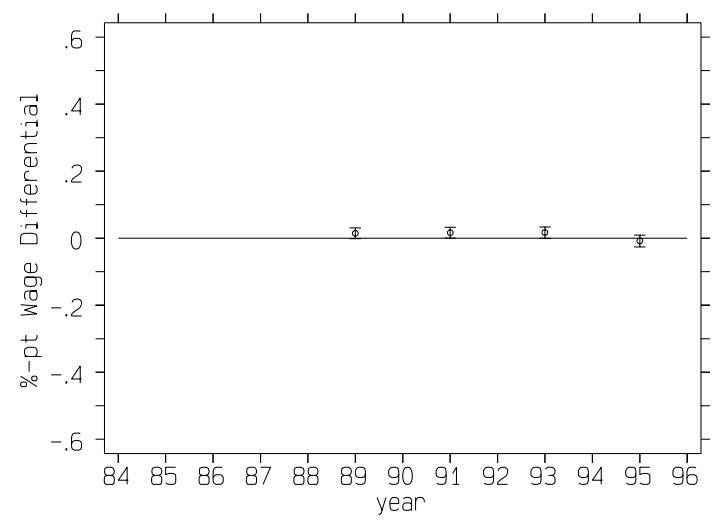

(b) Mikrozensus

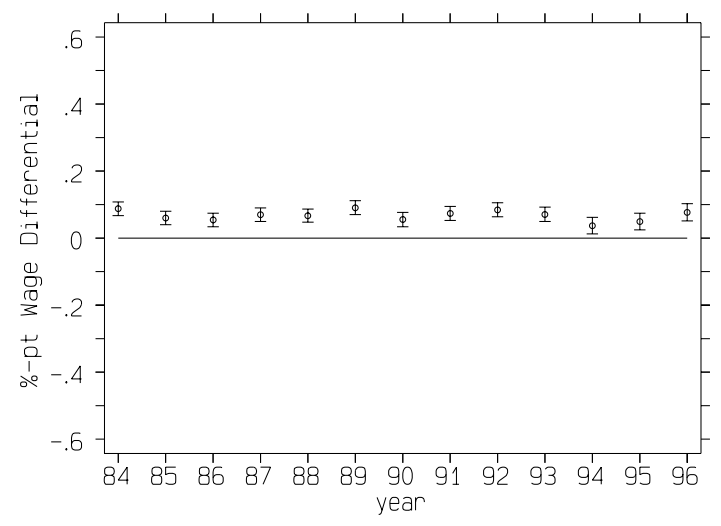

(d) CPS

Figure 5: III.2-Plastics 


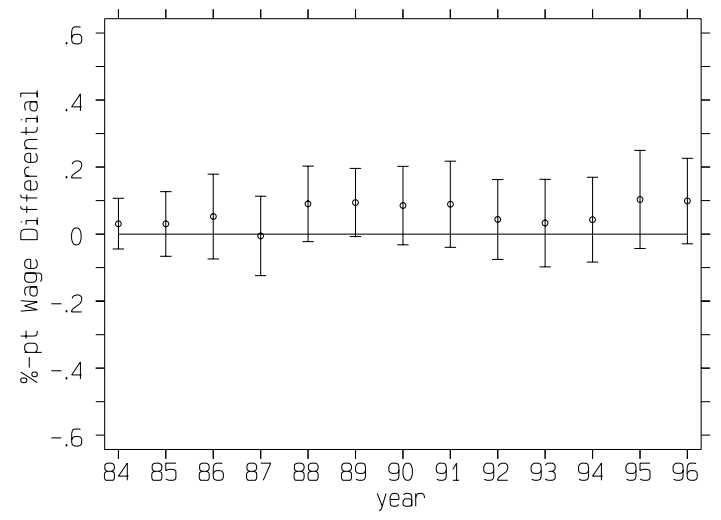

(a) GSOEP

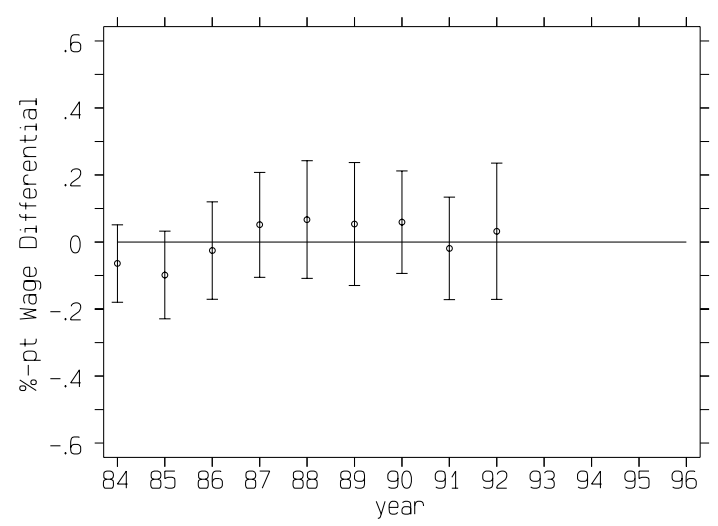

(c) PSID

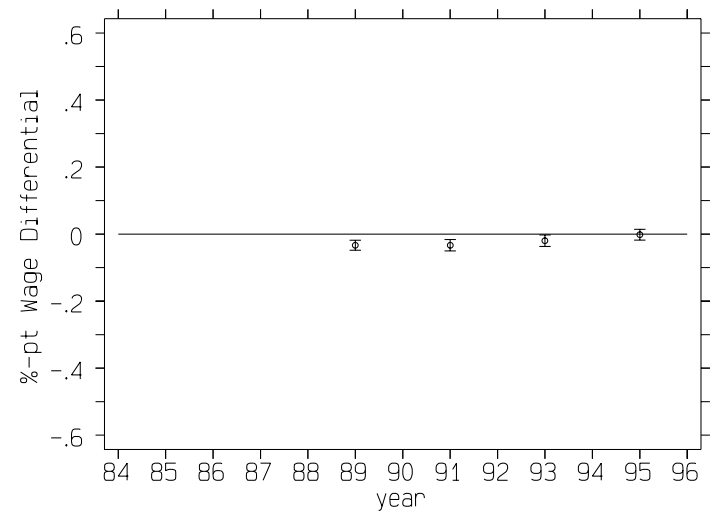

(b) Mikrozensus

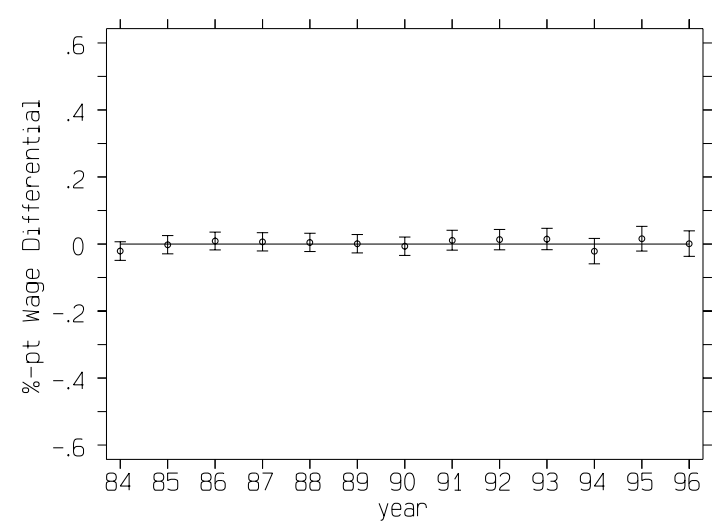

(d) CPS

Figure 6: III.3-Stone/Ceramics 


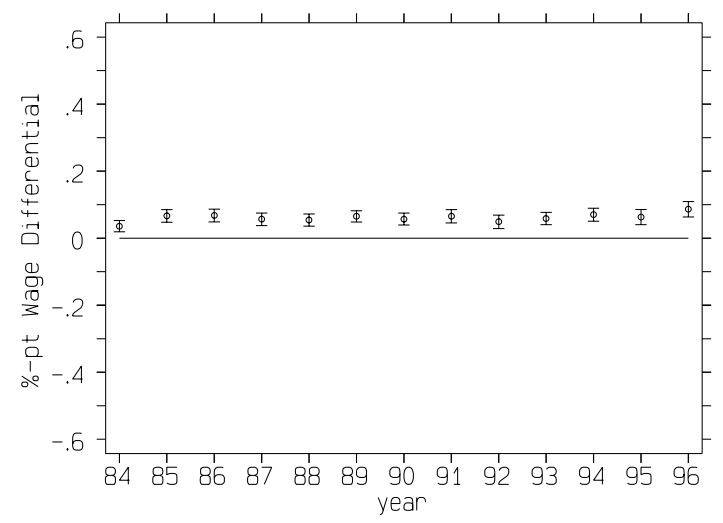

(a) GSOEP

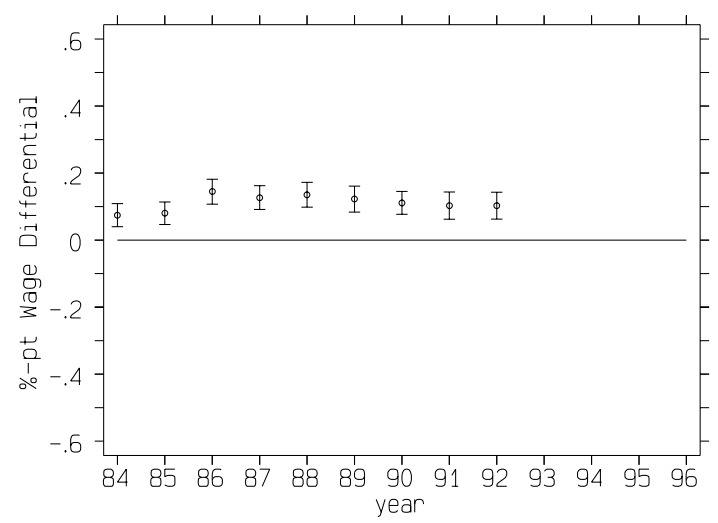

(c) PSID

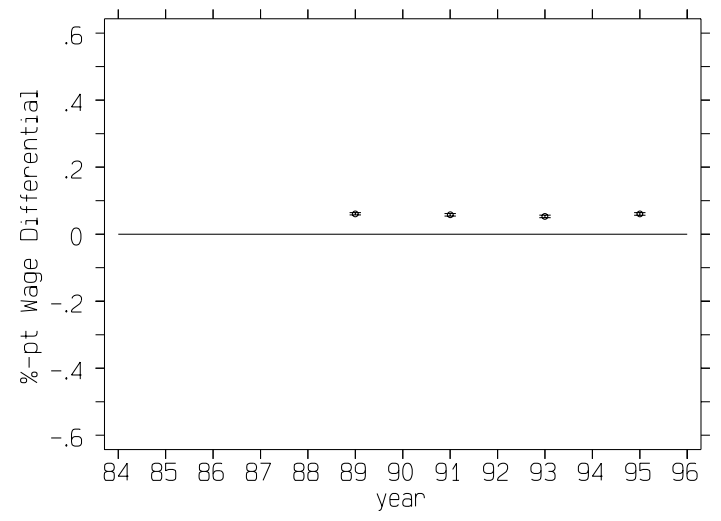

(b) Mikrozensus

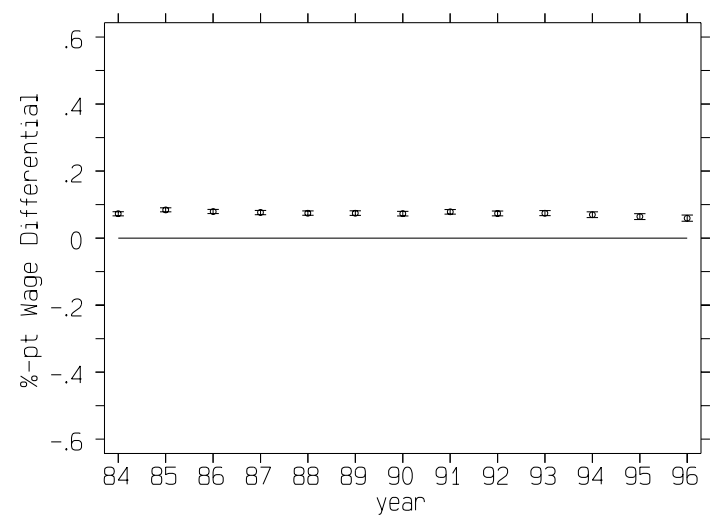

(d) CPS

Figure 7: III.4-Metal 


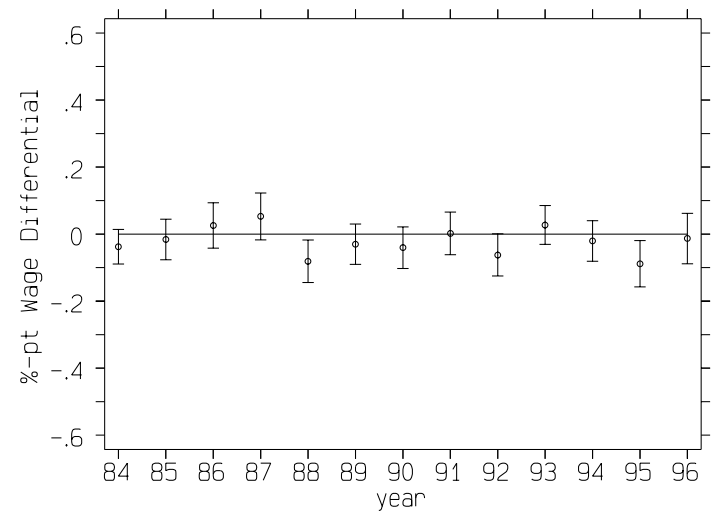

(a) GSOEP

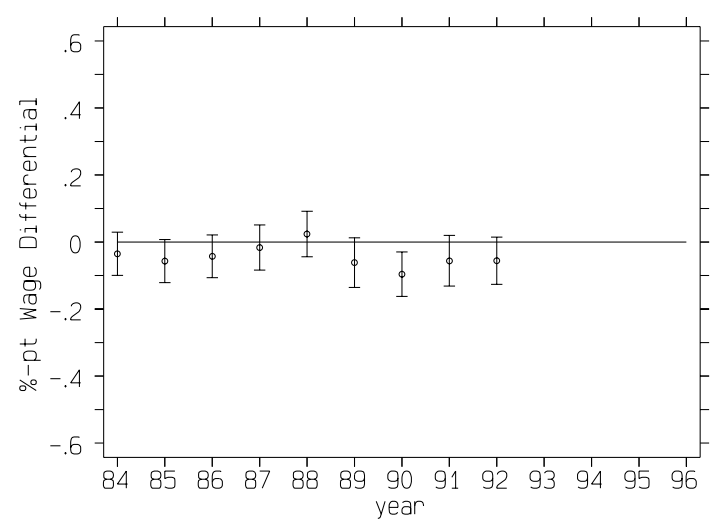

(c) PSID

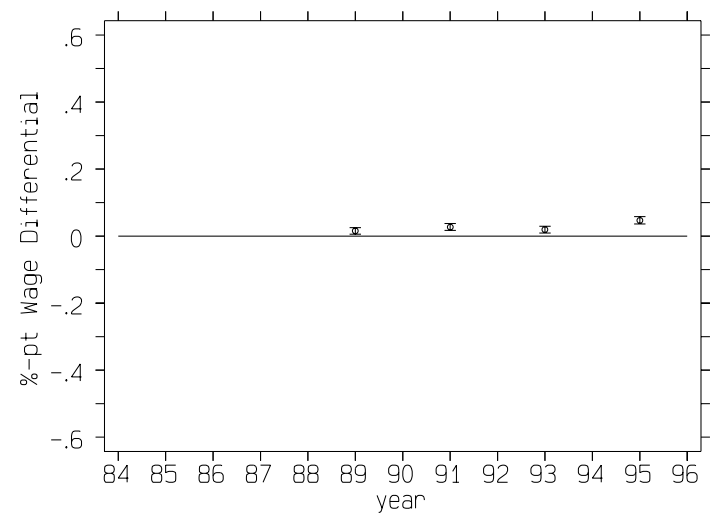

(b) Mikrozensus

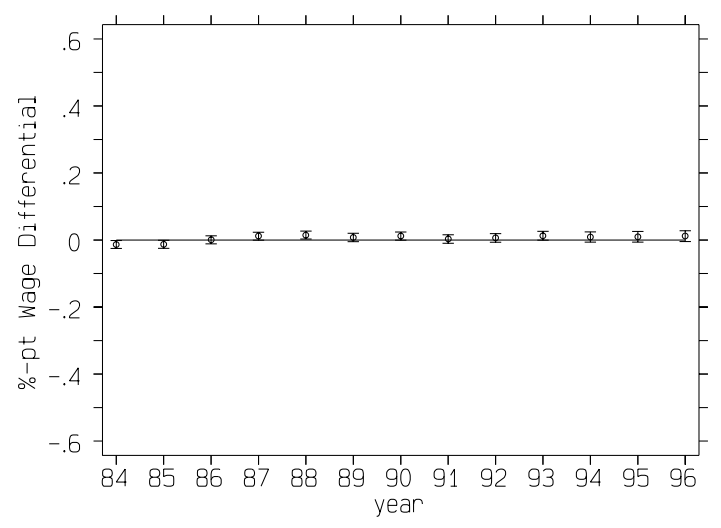

(d) CPS

Figure 8: III.5-Wood/Printing 


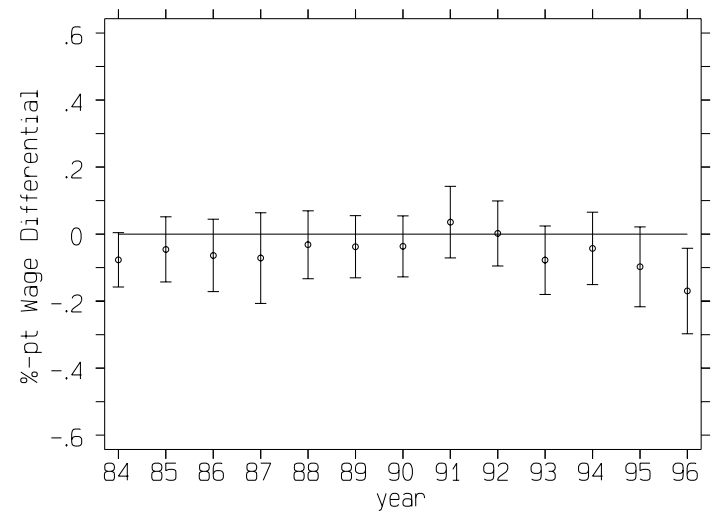

(a) GSOEP

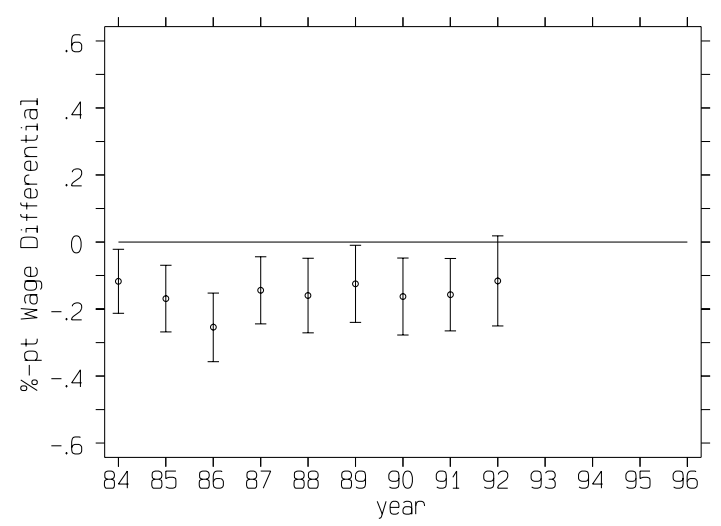

(c) PSID

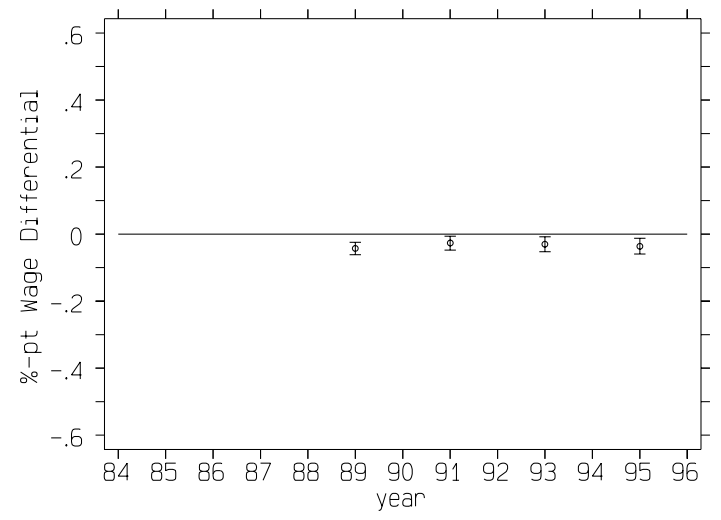

(b) Mikrozensus

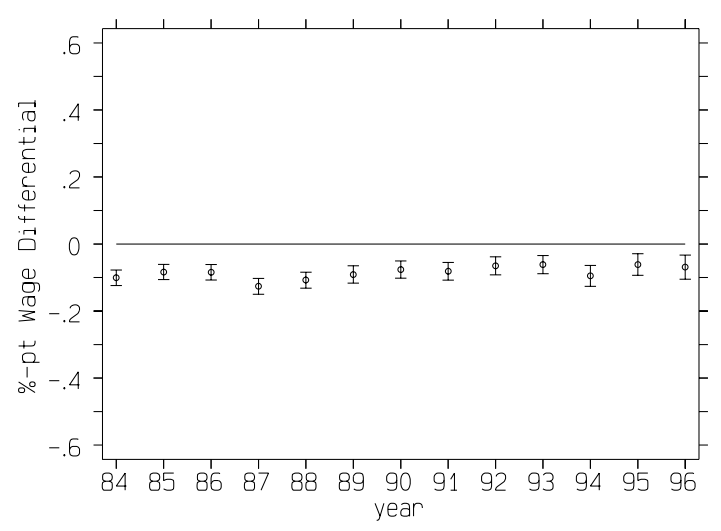

(d) CPS

Figure 9: III.6-Textiles/Clothes 


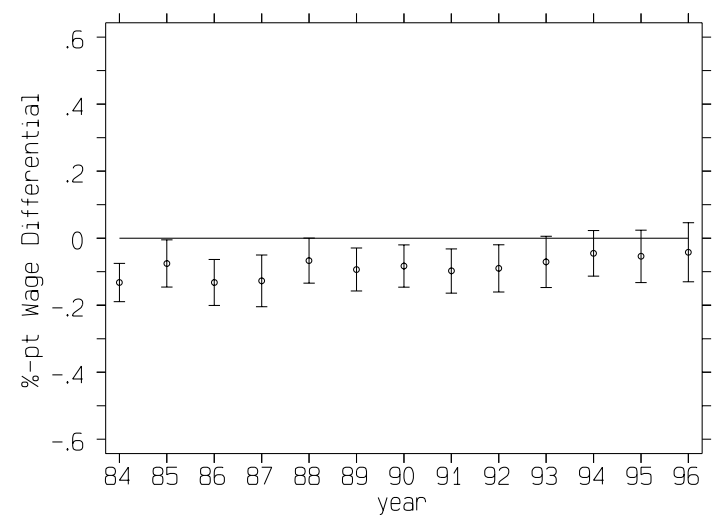

(a) GSOEP

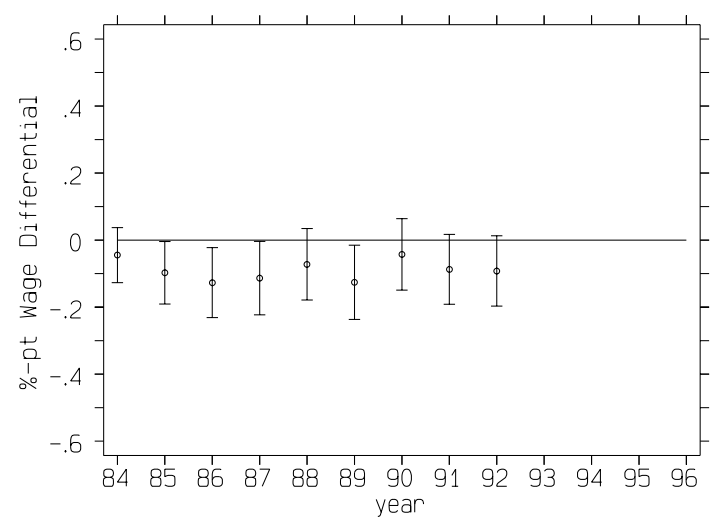

(c) PSID

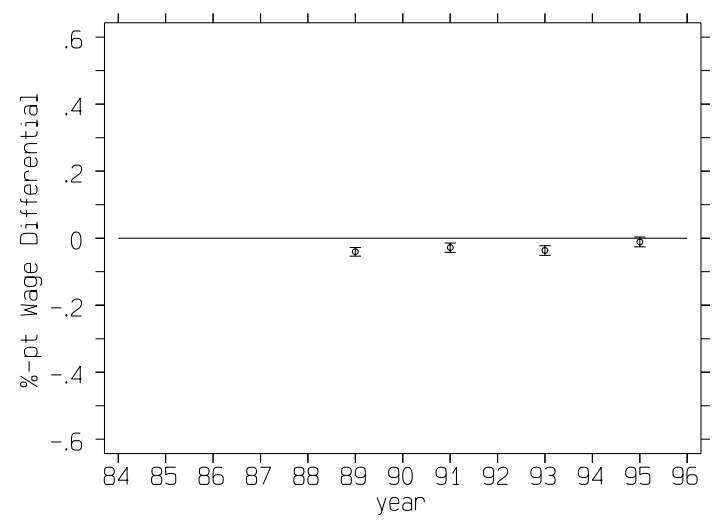

(b) Mikrozensus

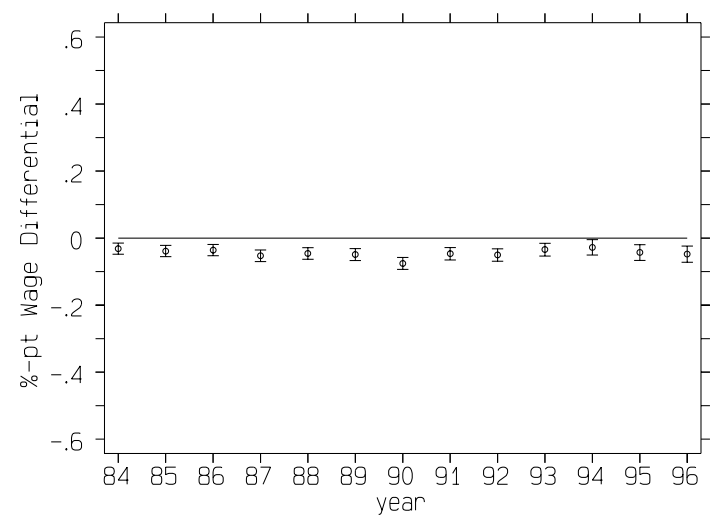

(d) CPS

Figure 10: III.7-Food 


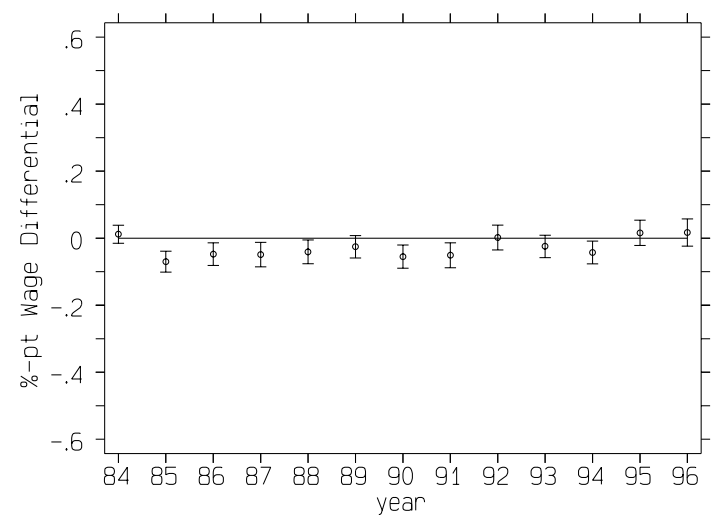

(a) GSOEP

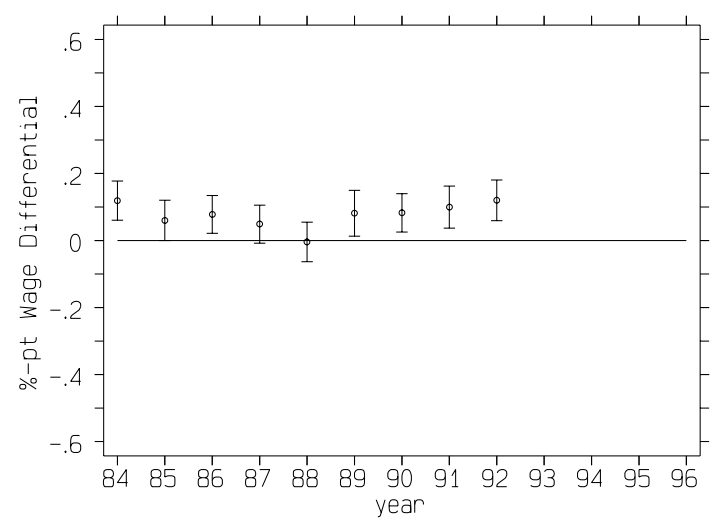

(c) PSID

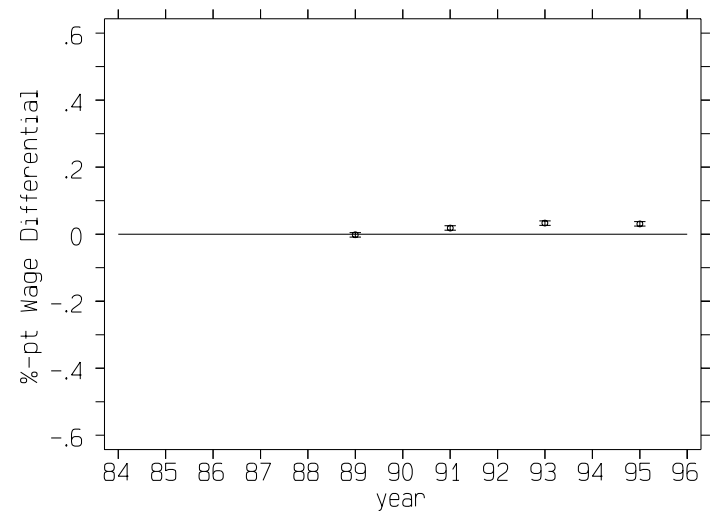

(b) Mikrozensus

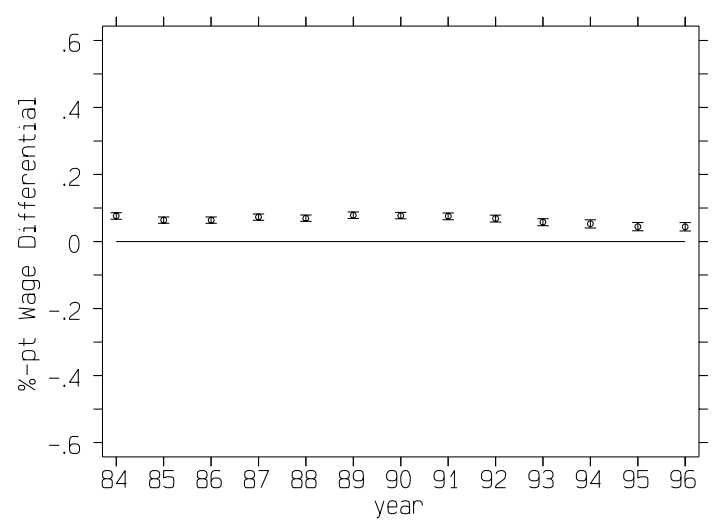

(d) CPS

Figure 11: IV-Construction 


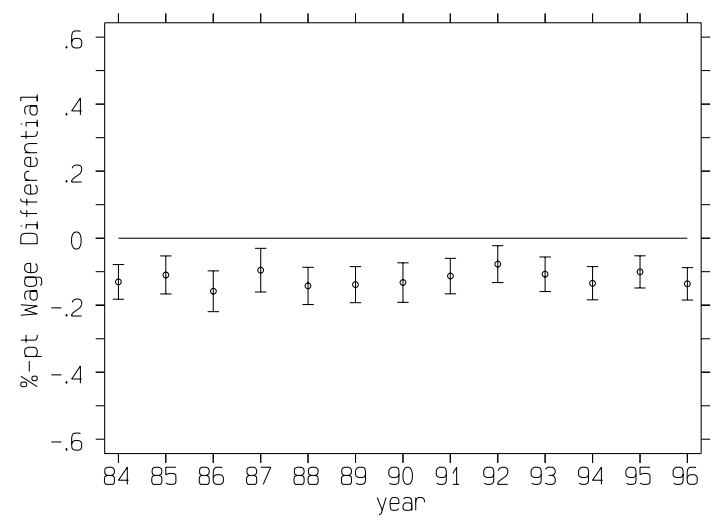

(a) GSOEP

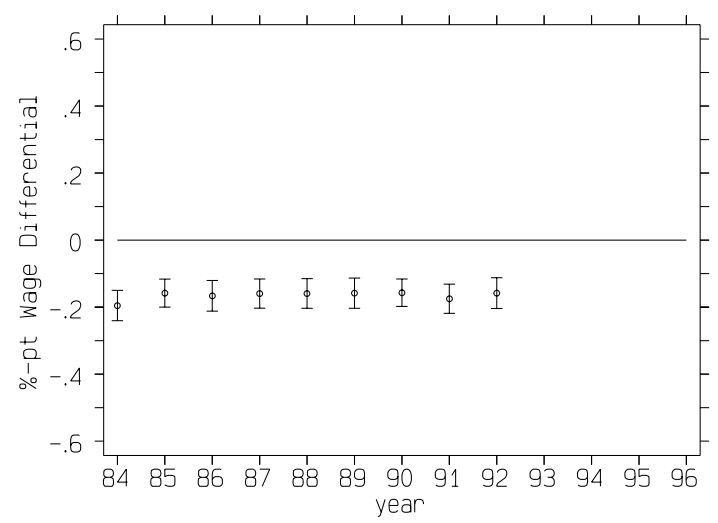

(c) PSID

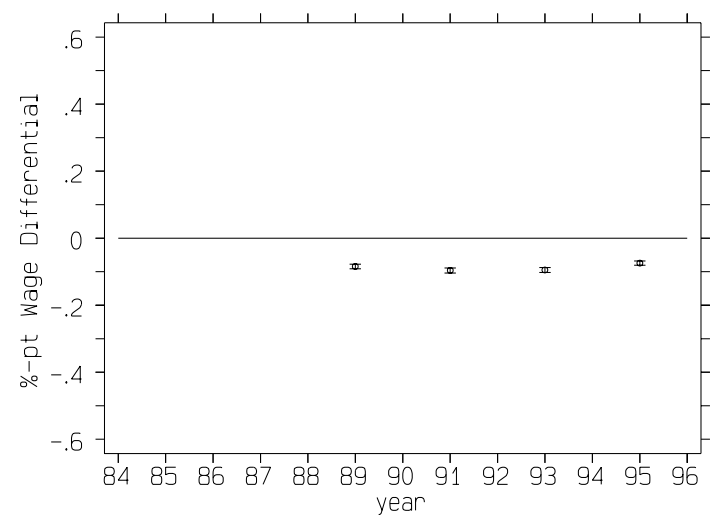

(b) Mikrozensus

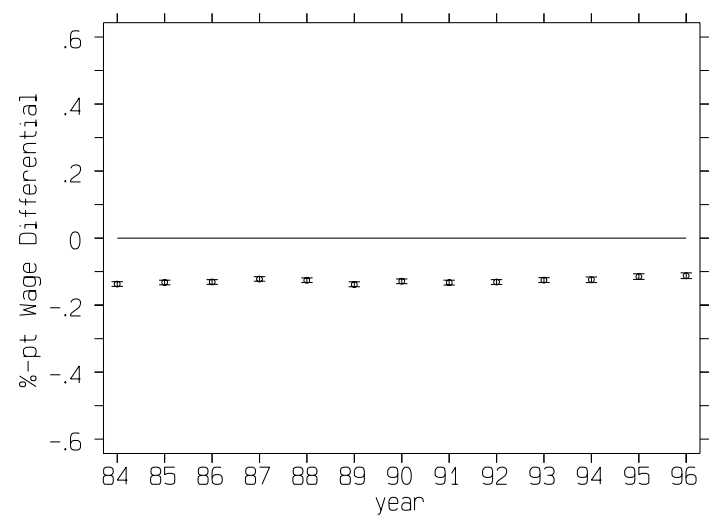

(d) CPS

Figure 12: V-Trade 


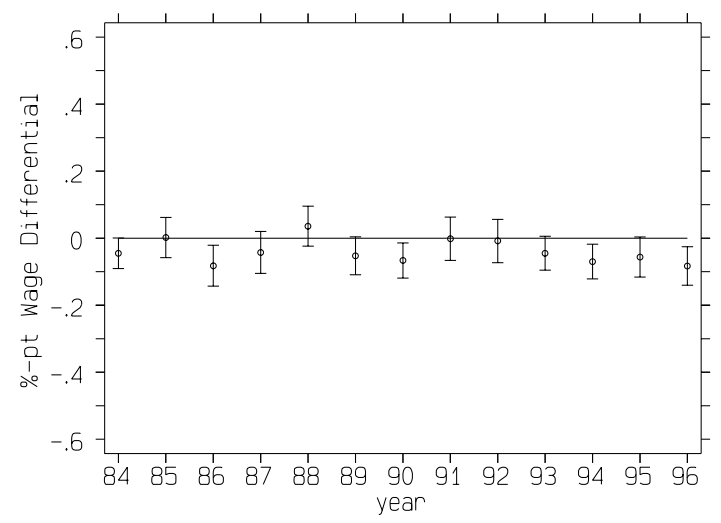

(a) GSOEP

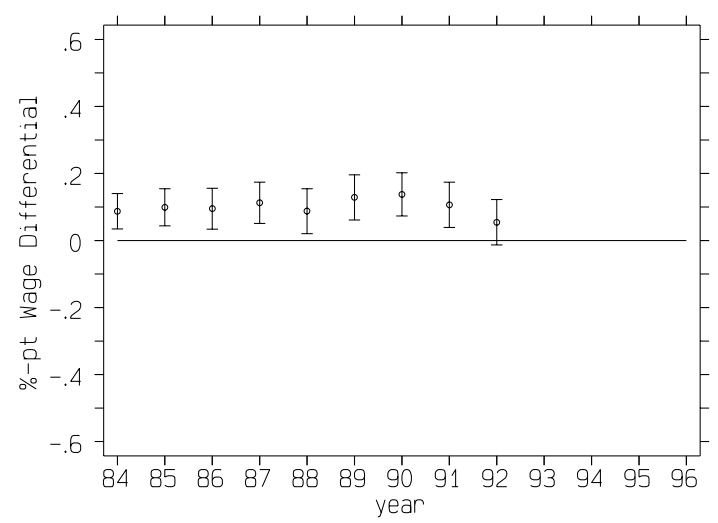

(c) PSID

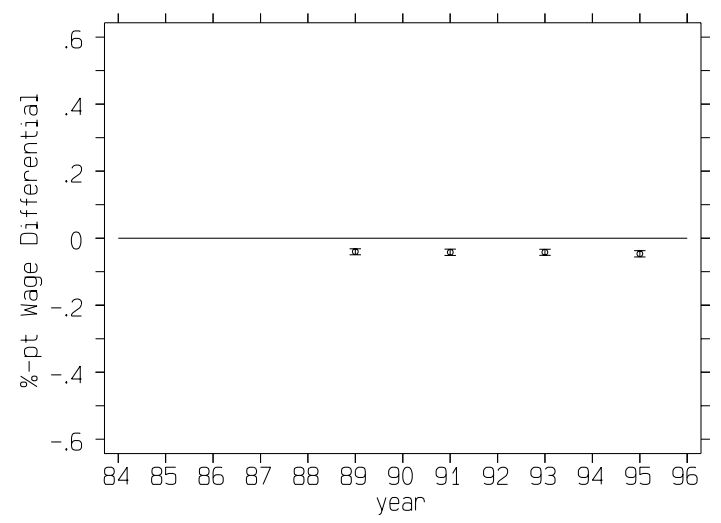

(b) Mikrozensus

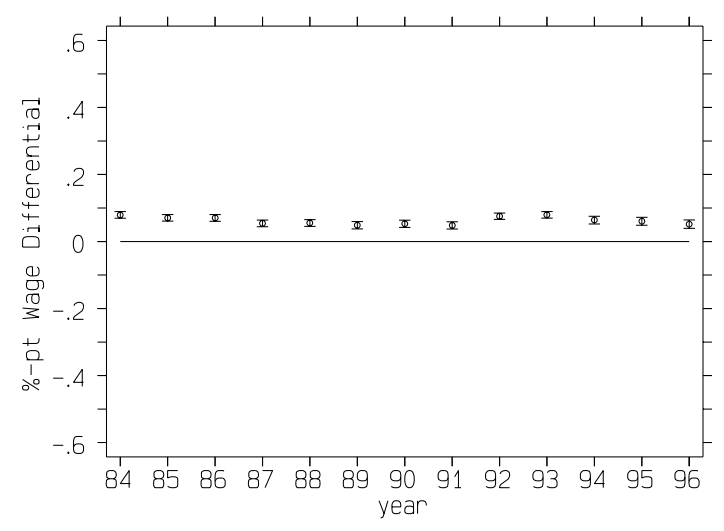

(d) CPS

Figure 13: VI-Transportation 


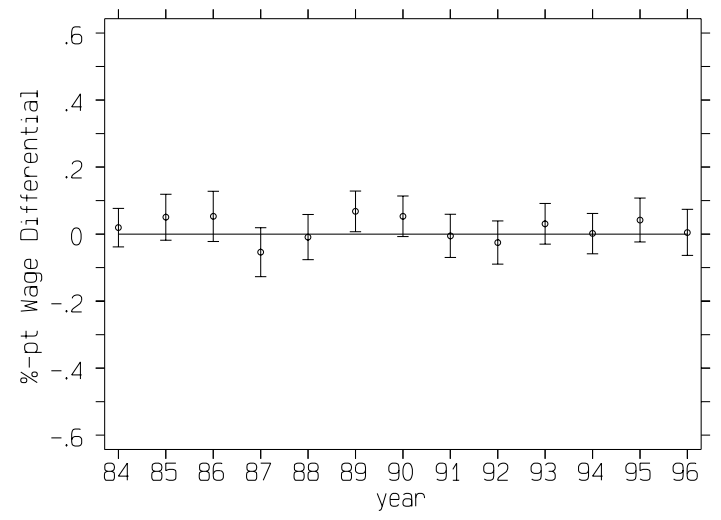

(a) GSOEP

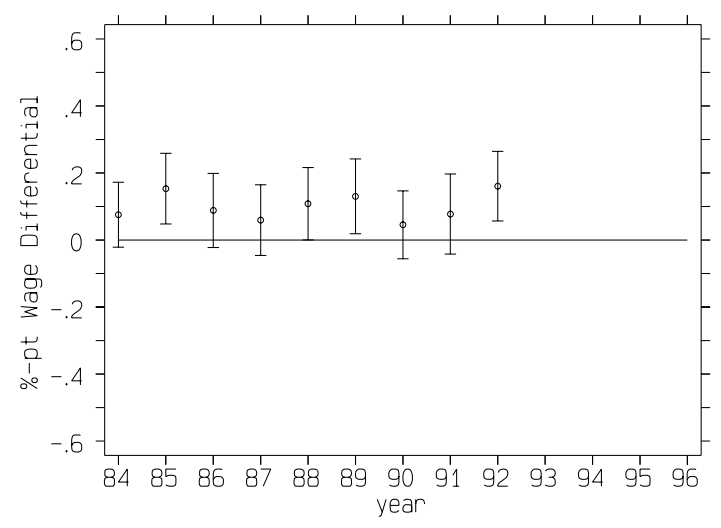

(c) PSID

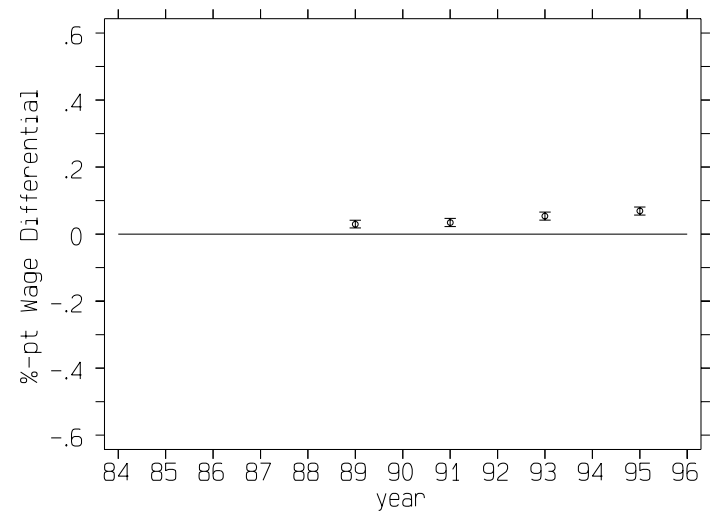

(b) Mikrozensus

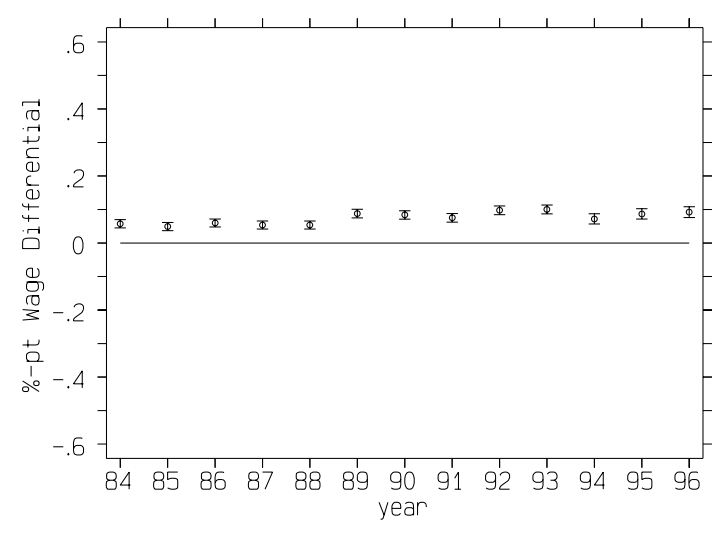

(d) CPS

Figure 14: VII-Banking/Insurance 


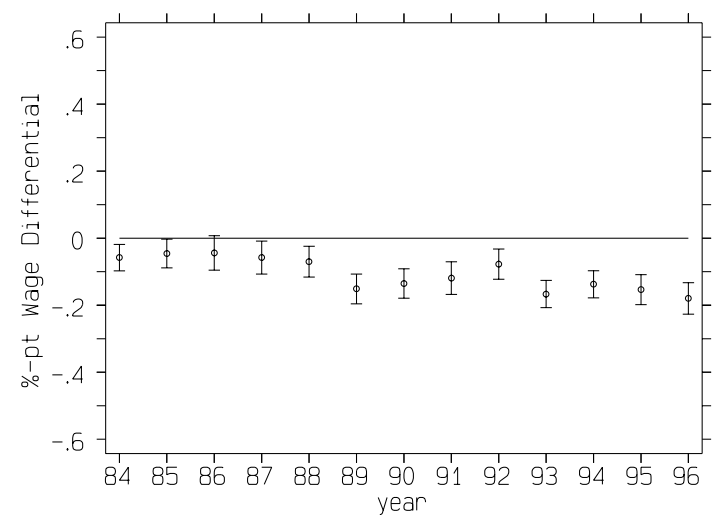

(a) GSOEP

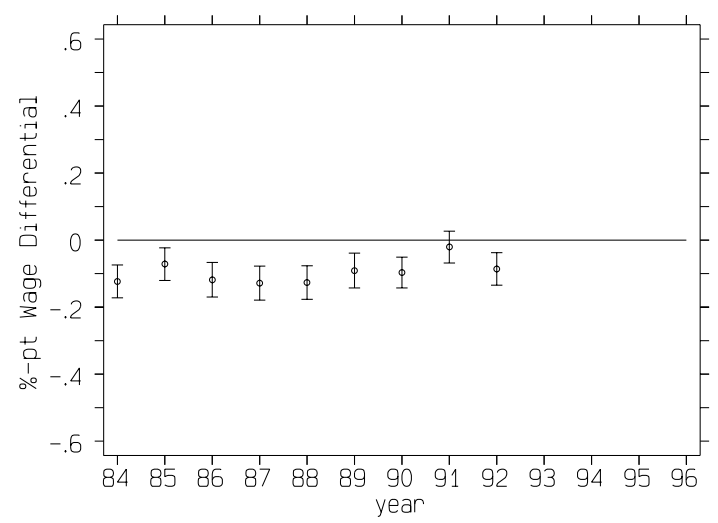

(c) PSID

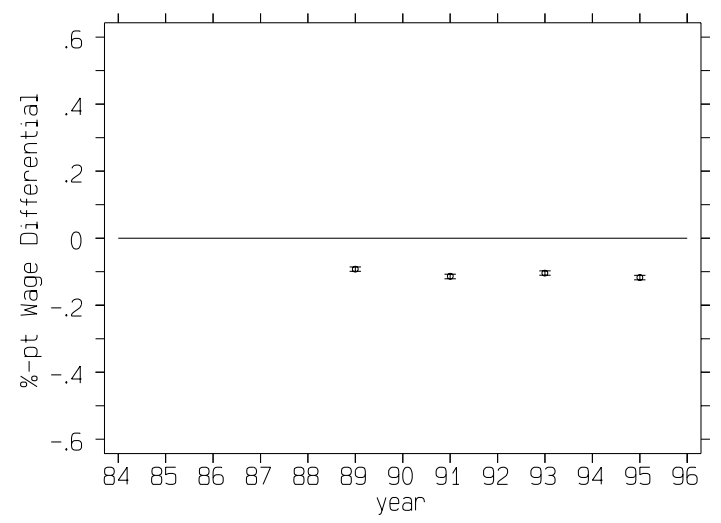

(b) Mikrozensus

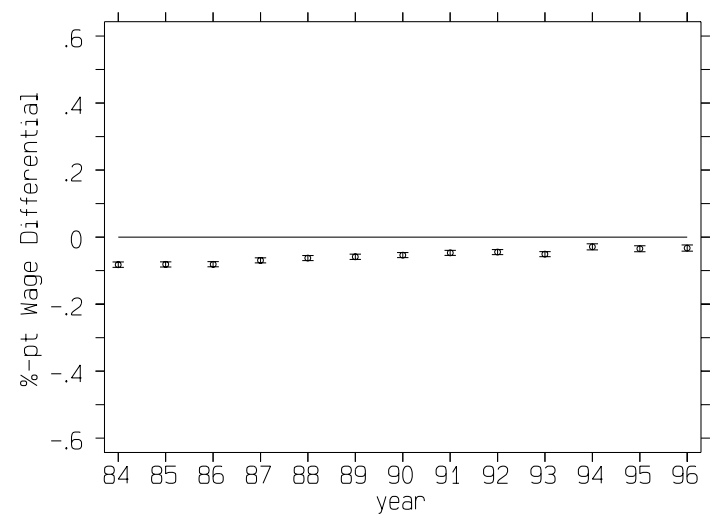

(d) CPS

Figure 15: VIII-Other Services 


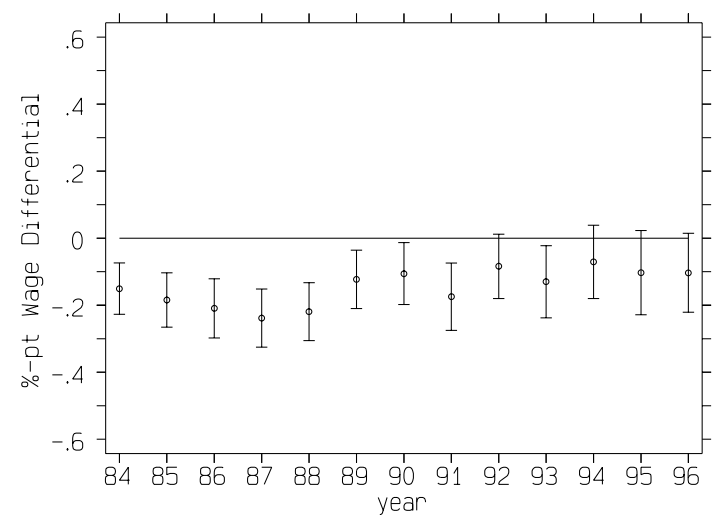

(a) GSOEP

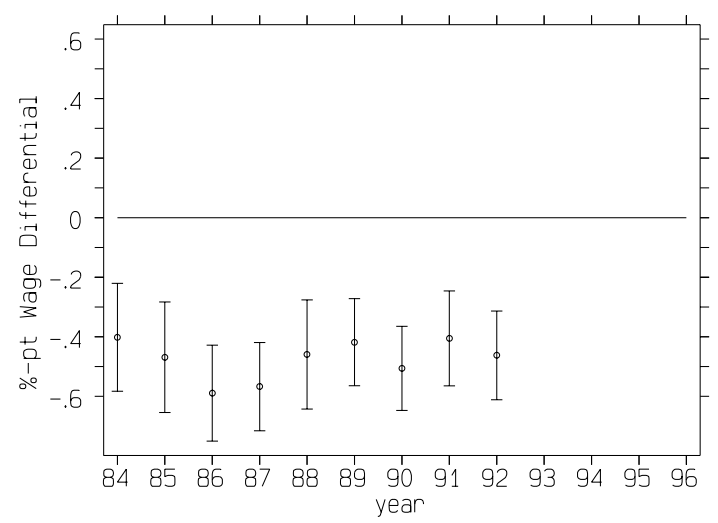

(c) PSID

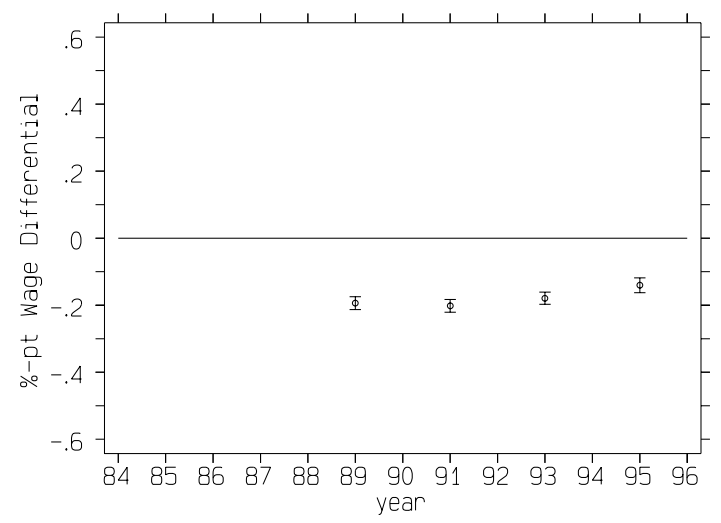

(b) Mikrozensus

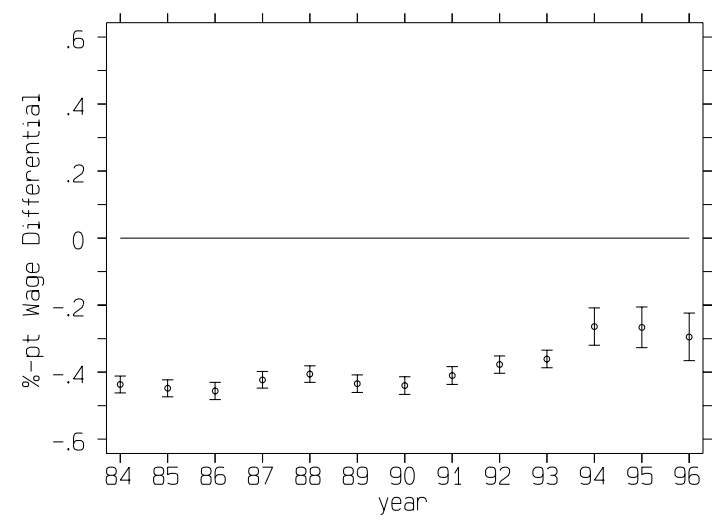

(d) CPS

Figure 16: IX-Non Profit 
Table 5: The German SOEP Pooled and Panel 84-96

\begin{tabular}{|c|c|c|c|c|}
\hline & Industry & Pooled 84-96 & RE Panel 84-96 & FE Panel RAW \\
\hline II & Energy/Mining & $\begin{array}{c}.09225 \\
(7.544) \\
{[.03322]}\end{array}$ & $\begin{array}{c}.03791 \\
(2.307) \\
{[.03322]}\end{array}$ & $\begin{array}{c}-.0122164 \\
(-0.601) \\
{[.03322]}\end{array}$ \\
\hline III.1 & Chemicals & $\left.\begin{array}{c}.10948 \\
(12.842 \\
.06680\end{array}\right\}$ & $\begin{array}{c}.06907 \\
(5.673) \\
{[.06680]}\end{array}$ & $\begin{array}{l}.0434529 \\
(2.836) \\
{[.06680]}\end{array}$ \\
\hline III. 2 & Plastics & $\begin{array}{l}-.01625 \\
(-0.876) \\
{[.01479]}\end{array}$ & $\begin{array}{l}.02689 \\
(1.314) \\
{[.01479]}\end{array}$ & $\begin{array}{l}.0556575 \\
(2.384) \\
{[.01479]}\end{array}$ \\
\hline III.3 & Stone/Ceramics & $\begin{array}{c}.05579 \\
(2.907) \\
{[.01373]}\end{array}$ & $\left.\begin{array}{l}-.01451 \\
(-0.699 \\
{[.01373}\end{array}\right]$ & $\left.\begin{array}{l}-.045063 \\
(-1.909 \\
{[.01373}\end{array}\right]$ \\
\hline III. 4 & Metal & $\left.\begin{array}{l}.06176 \\
(19.186) \\
{[.34228}\end{array}\right]$ & $\begin{array}{c}.04031 \\
(8.983) \\
{[.34228]}\end{array}$ & $\begin{array}{l}.0311911 \\
(5.282) \\
{[.34228]}\end{array}$ \\
\hline III. 5 & Wood/Printing & $\begin{array}{l}-.02038 \\
(-1.908) \\
{[.04403]}\end{array}$ & $\begin{array}{l}-.01494 \\
(-1.019) \\
{[.04403]}\end{array}$ & $\begin{array}{c}.0093112 \\
(0.484) \\
{[.04403]}\end{array}$ \\
\hline III. 6 & Textiles/Clothes & $\left.\begin{array}{l}-.06978 \\
(-4.006 \\
{[.01665}\end{array}\right]$ & $\left.\begin{array}{c}-.04721 \\
(-2.220 \\
{[.01665}\end{array}\right]$ & $\left.\begin{array}{c}-.0415542 \\
(-1.646) \\
{[.01665}\end{array}\right]$ \\
\hline III. 7 & Food & $\begin{array}{l}-.08712 \\
(-7.411) \\
{[.03606]}\end{array}$ & $\begin{array}{l}-.03324 \\
(-2.238) \\
{[.03606]}\end{array}$ & $\begin{array}{l}.0158818 \\
(0.881) \\
{[.03606]}\end{array}$ \\
\hline IV & Construction & $\begin{array}{l}-.02765 \\
(-4.751) \\
{[.14194]}\end{array}$ & $\begin{array}{c}-.00113 \\
(-0.148) \\
{[.14194]}\end{array}$ & $\begin{array}{c}.0321181 \\
(3.313) \\
{[.14194]}\end{array}$ \\
\hline V & Trade & $\begin{array}{c}-.12374 \\
(-13.504) \\
{[.06769]}\end{array}$ & $\left.\begin{array}{l}-.04945 \\
(-5.413) \\
{[.06769}\end{array}\right]$ & $\left.\begin{array}{r}-.0233682 \\
(-2.307 \\
{[.06769}\end{array}\right]$ \\
\hline VI & Transportation & $\left.\begin{array}{l}-.04597 \\
(-4.792 \\
.05387\end{array}\right]$ & $\left.\begin{array}{l}-.05749 \\
(-4.626 \\
{[.05387}\end{array}\right]$ & $\left.\begin{array}{l}-.045278 \\
(-2.884 \\
{[.05387}\end{array}\right]$ \\
\hline VII & Banking & $\begin{array}{c}.01881 \\
(1.724) \\
{[.05653]}\end{array}$ & $\begin{array}{l}-.02786 \\
(-1.534) \\
{[.05653]}\end{array}$ & $\begin{array}{c}-.1375466 \\
(-4.734) \\
{[.05653]}\end{array}$ \\
\hline VIII & Other Services & $\begin{array}{c}-.10827 \\
(-14.301) \\
{[.09170]}\end{array}$ & $\begin{array}{l}-.07643 \\
(-8.060) \\
{[.09170]}\end{array}$ & $\begin{array}{c}-.0567715 \\
(-4.853) \\
{[.09170]}\end{array}$ \\
\hline IX & Non Profit & $\left.\begin{array}{l}-.15503 \\
(-9.771 \\
.02064\end{array}\right)$ & $\left.\begin{array}{l}-.09865 \\
(-4.706) \\
{[.02064}\end{array}\right]$ & $\left.\begin{array}{c}-.0593163 \\
(-2.219 \\
.02064\end{array}\right\}$ \\
\hline & $\begin{array}{l}\mathrm{N} \\
\mathrm{F} \\
\text { Prob }(\mathrm{F}) \\
\mathrm{R}^{2} \\
\text { Adj-R }{ }^{2} \\
\text { Root MSE } \\
\mathrm{S}_{\beta}^{*} F U L L \\
\mathrm{~S}_{\beta}^{*} R A W\end{array}$ & $\begin{array}{c}11286 \\
247.19 \\
0.0000 \\
0.4616 \\
0.4597 \\
.2401 \\
.07475 \\
.09700\end{array}$ & $\begin{array}{c}11286 \\
- \\
- \\
0.4320 \\
- \\
- \\
.04501 \\
.03733\end{array}$ & $\begin{array}{c}11286 \\
118.22 \\
0.0000 \\
0.0261 \\
- \\
- \\
- \\
.04589\end{array}$ \\
\hline
\end{tabular}


Table 6: The German SOEP 84-89

\begin{tabular}{|c|c|c|c|c|c|c|c|}
\hline & Industry & 1984 & 1985 & 1986 & 1987 & 1988 & 1989 \\
\hline II & Energy/Mining & $\begin{array}{c}.14964 \\
(4.223) \\
{[.03738]}\end{array}$ & $\begin{array}{c}.08243 \\
(1.707) \\
{[.02702]}\end{array}$ & $\begin{array}{c}.07383 \\
(1.460) \\
{[.02840]}\end{array}$ & $\begin{array}{l}.0917944 \\
(1.811) \\
{[.02957]}\end{array}$ & $\begin{array}{c}.10238 \\
(2.261) \\
{[.03206]}\end{array}$ & $\begin{array}{c}.04857 \\
(1.113) \\
{[.02953]}\end{array}$ \\
\hline III.1 & Chemicals & $\begin{array}{c}.11074 \\
(4.006) \\
{[.06074]}\end{array}$ & $\begin{array}{l}.08975 \\
(2.685) \\
{[.05513]}\end{array}$ & $\begin{array}{c}.11509 \\
(3.427) \\
{[.06250]}\end{array}$ & $\begin{array}{c}.1433325 \\
(4.186) \\
{[.06257]}\end{array}$ & $\begin{array}{c}.12499 \\
(4.074) \\
{[.06769]}\end{array}$ & $\begin{array}{c}.05551 \\
(1.859) \\
{[.06118]}\end{array}$ \\
\hline III. 2 & Plastics & $\begin{array}{c}-.06963 \\
(-1.266) \\
{[.01588]}\end{array}$ & $\begin{array}{l}-.06920 \\
(-1.170) \\
{[.01837]}\end{array}$ & $\begin{array}{l}-.08023 \\
(-1.335) \\
{[.02045]}\end{array}$ & $\begin{array}{r}-.0856173 \\
(-1.274) \\
{[.01706]}\end{array}$ & $\begin{array}{l}-.06370 \\
(-0.922) \\
{[.01425]}\end{array}$ & $\begin{array}{l}.06265 \\
(1.170) \\
{[.02004]}\end{array}$ \\
\hline III.3 & Stone/Ceramics & $\begin{array}{c}.03121 \\
(0.680) \\
{[.02242]}\end{array}$ & $\begin{array}{c}.03023 \\
(0.515) \\
{[.01837]}\end{array}$ & $\begin{array}{c}.05229 \\
(0.679) \\
{[.01250]}\end{array}$ & $\left.\begin{array}{l}-.0054878 \\
(-0.076) \\
.01478\end{array}\right]$ & $\begin{array}{c}.09016 \\
(1.317) \\
{[.01425]}\end{array}$ & $\begin{array}{c}.09430 \\
(1.524) \\
{[.01476]}\end{array}$ \\
\hline III.4 & Metal & $\begin{array}{c}.03570 \\
(3.492) \\
{[.32242]}\end{array}$ & $\begin{array}{l}.06639 \\
(5.827) \\
{[.34270]}\end{array}$ & $\begin{array}{c}.06761 \\
(5.855) \\
{[.36363]}\end{array}$ & $\begin{array}{l}.0562971 \\
(4.927) \\
{[.37883]}\end{array}$ & $\begin{array}{c}.05396 \\
(4.860) \\
{[.35985]}\end{array}$ & $\begin{array}{c}.06512 \\
(6.388) \\
{[.36814]}\end{array}$ \\
\hline III.5 & Wood/Printing & $\begin{array}{l}-.03780 \\
(-1.204) \\
{[.04766]}\end{array}$ & $\begin{array}{l}-.01598 \\
(-0.435) \\
{[.04648]}\end{array}$ & $\begin{array}{c}.02572 \\
(0.625) \\
{[.04318]}\end{array}$ & $\begin{array}{c}.052535 \\
(1.236) \\
{[.04209]}\end{array}$ & $\begin{array}{c}-.08102 \\
(-2.104) \\
{[.04394]}\end{array}$ & $\begin{array}{l}-.03011 \\
(-0.823) \\
{[.04219]}\end{array}$ \\
\hline III. 6 & Textiles/Clothes & $\left.\begin{array}{l}-.07688 \\
(-1.558 \\
{[.01962}\end{array}\right]$ & $\left.\begin{array}{c}-.04563 \\
(-0.772 \\
{[.01837}\end{array}\right]$ & $\left.\begin{array}{c}-.06357 \\
(-0.969 \\
{[.01704}\end{array}\right]$ & $\left.\begin{array}{r}-.0716361 \\
(-0.871) \\
{[.01137}\end{array}\right]$ & $\left.\begin{array}{c}-.03187 \\
(-0.517 \\
{[.01781}\end{array}\right]$ & $\left.\begin{array}{l}-.03765 \\
(-0.668 \\
{[.01793}\end{array}\right]$ \\
\hline III.7 & Food & $\begin{array}{l}-.13237 \\
(-3.811) \\
{[.03925]}\end{array}$ & $\begin{array}{l}-.07545 \\
(-1.764) \\
{[.03459]}\end{array}$ & $\begin{array}{l}-.13225 \\
(-3.172) \\
{[.04204]}\end{array}$ & $\begin{array}{l}-.1274397 \\
(-2.717) \\
{[.03412]}\end{array}$ & $\begin{array}{l}-.06694 \\
(-1.640) \\
{[.03919]}\end{array}$ & $\begin{array}{l}-.09345 \\
(-2.394) \\
{[.03691]}\end{array}$ \\
\hline IV & Construction & $\begin{array}{c}.01155 \\
(0.707) \\
{[.16635]}\end{array}$ & $\begin{array}{l}-.07011 \\
(-3.683) \\
{[.16216]}\end{array}$ & $\begin{array}{l}-.04756 \\
(-2.314) \\
{[.15681]}\end{array}$ & $\begin{array}{c}-.0490247 \\
(-2.209) \\
{[.14334]}\end{array}$ & $\begin{array}{l}-.04085 \\
(-1.893) \\
{[.13539]}\end{array}$ & $\begin{array}{c}-.02562 \\
(-1.259) \\
{[.13396]}\end{array}$ \\
\hline $\mathrm{V}$ & Trade & $\left.\begin{array}{c}-.13037 \\
(-4.138 \\
{[.05140}\end{array}\right]$ & $\left.\begin{array}{c}-.10981 \\
(-3.183) \\
{[.06054}\end{array}\right]$ & $\left.\begin{array}{l}-.15848 \\
(-4.288) \\
.05681\end{array}\right]$ & $\left.\begin{array}{l}-.0955669 \\
(-2.412 \\
.05119\end{array}\right]$ & $\left.\begin{array}{c}-.14245 \\
(-4.208) \\
{[.06294}\end{array}\right]$ & $\left.\begin{array}{c}-.13870 \\
(-4.234) \\
{[.06540}\end{array}\right]$ \\
\hline VI & Transportation & $\left.\begin{array}{l}-.04509 \\
(-1.632 \\
{[.06074}\end{array}\right]$ & $\begin{array}{c}.00186 \\
(0.051) \\
{[.04756]}\end{array}$ & $\left.\begin{array}{l}-.08206 \\
(-2.212 \\
.05227\end{array}\right]$ & $\left.\begin{array}{r}-.0424383 \\
-1.115 \\
.05233\end{array}\right]$ & $\begin{array}{c}.03576 \\
(0.984) \\
{[.04988]}\end{array}$ & $\left.\begin{array}{c}-.05264 \\
(-1.527 \\
{[.04746}\end{array}\right]$ \\
\hline VII & Banking & $\begin{array}{c}.01905 \\
(0.546) \\
{[.04859]}\end{array}$ & $\begin{array}{c}.05028 \\
(1.207) \\
{[.04540]}\end{array}$ & $\begin{array}{c}.05293 \\
(1.162) \\
{[.04204]}\end{array}$ & $\begin{array}{c}-.0540249 \\
(-1.216) \\
{[.04778]}\end{array}$ & $\begin{array}{l}-.00890 \\
(-0.217) \\
{[.04988]}\end{array}$ & $\begin{array}{c}.06770 \\
(1.838) \\
{\left[\begin{array}{c}.05907]\end{array}\right]}\end{array}$ \\
\hline VIII & Other Services & $\begin{array}{l}-.05822 \\
(-2.426) \\
{[.08504]}\end{array}$ & $\begin{array}{l}-.04565 \\
(-1.753) \\
{[.09621]}\end{array}$ & $\begin{array}{l}-.04401 \\
(-1.410) \\
{[.07613]}\end{array}$ & $\begin{array}{c}-.0579626 \\
(-1.938) \\
{[.08646]}\end{array}$ & $\begin{array}{l}-.07014 \\
(-2.511) \\
{[.08788]}\end{array}$ & $\begin{array}{l}-.15145 \\
(-5.614) \\
{[.08227]}\end{array}$ \\
\hline IX & Non Profit & $\left.\begin{array}{l}-.15050 \\
(-3.229 \\
{[.02242}\end{array}\right]$ & $\left.\begin{array}{l}-.18436 \\
(-3.739 \\
{[.02702}\end{array}\right]$ & $\left.\begin{array}{l}-.20955 \\
(-3.899 \\
{[.02613}\end{array}\right]$ & $\left.\begin{array}{l}-.2384611 \\
(-4.521) \\
{[.02844}\end{array}\right]$ & $\left.\begin{array}{c}-.21923 \\
(-4.174) \\
{[.02494}\end{array}\right]$ & $\left.\begin{array}{l}-.12289 \\
(-2.322 \\
{[.02109}\end{array}\right]$ \\
\hline & $\begin{array}{l}\mathrm{N} \\
\mathrm{F} \\
\text { Prob }(\mathrm{F}) \\
\mathrm{R}^{2} \\
\text { Adj-R } \\
\text { Root MSE } \\
\mathrm{S}_{\beta}^{*} F U L L \\
\mathrm{~S}_{\beta}^{*} R A W\end{array}$ & $\begin{array}{l}1070 \\
26.80 \\
0.0000 \\
0.4098 \\
0.3945 \\
.22696 \\
.06429 \\
.07377\end{array}$ & $\begin{array}{c}925 \\
25.36 \\
0.0000 \\
0.4329 \\
0.4158 \\
.24322 \\
.06603 \\
.08839\end{array}$ & $\begin{array}{c}880 \\
24.60 \\
0.0000 \\
0.4380 \\
0.4202 \\
.25497 \\
.07860 \\
.10134\end{array}$ & $\begin{array}{c}879 \\
25.07 \\
0.0000 \\
0.4334 \\
0.4161 \\
.25986 \\
.07406 \\
.08722\end{array}$ & $\begin{array}{c}842 \\
27.57 \\
0.0000 \\
0.4777 \\
0.4603 \\
.23691 \\
.07328 \\
.08186\end{array}$ & $\begin{array}{c}948 \\
28.09 \\
0.0000 \\
0.4519 \\
0.4358 \\
.23238 \\
.07454 \\
.09131\end{array}$ \\
\hline
\end{tabular}


Table 7: The German SOEP 90-96

\begin{tabular}{|c|c|c|c|c|c|c|c|c|}
\hline & Industry & 1990 & 1991 & 1992 & 1993 & 1994 & 1995 & 1996 \\
\hline II & Energy/Mining & $\begin{array}{c}.11845 \\
(2.729) \\
{[.03138]}\end{array}$ & $\begin{array}{c}.08816 \\
(2.189) \\
{[.04182]}\end{array}$ & $\begin{array}{c}.04433 \\
(1.049) \\
{[.03800]}\end{array}$ & $\begin{array}{c}.05462 \\
(1.252) \\
{[.03009]}\end{array}$ & $\begin{array}{c}.14258 \\
(3.226) \\
{[.03015]}\end{array}$ & $\begin{array}{c}.10717 \\
(2.525) \\
{[.04033]}\end{array}$ & $\begin{array}{c}.07770 \\
\left(\begin{array}{c}1.728 \\
{[.03805}\end{array}\right]\end{array}$ \\
\hline III.1 & Chemicals & $\begin{array}{c}.12836 \\
(4.109) \\
{[.05952]}\end{array}$ & $\begin{array}{c}.06881 \\
(2.265) \\
{[.07224]}\end{array}$ & $\begin{array}{c}.07227 \\
(2.401) \\
{[.07208]}\end{array}$ & $\begin{array}{c}.13734 \\
(5.163) \\
{[.07754]}\end{array}$ & $\begin{array}{c}.13422 \\
(5.069) \\
{[.08040]}\end{array}$ & $\begin{array}{c}.10338 \\
(3.285) \\
{[.07236]}\end{array}$ & $\begin{array}{c}.13312 \\
(4.047) \\
{[.07086]}\end{array}$ \\
\hline III. 2 & Plastics & $\begin{array}{c}.11039 \\
(1.994) \\
{[.01948]}\end{array}$ & $\begin{array}{c}.11846 \\
(1.330) \\
{[.00887]}\end{array}$ & $\begin{array}{l}-.10218 \\
(-1.321) \\
{[.01179]}\end{array}$ & $\begin{array}{c}-.01153 \\
(-0.177) \\
{[.01388]}\end{array}$ & $\begin{array}{c}.04658 \\
(0.601) \\
{[.01005]}\end{array}$ & $\begin{array}{c}.05794 \\
(0.604) \\
{[.00830]}\end{array}$ & $\left.\begin{array}{c}-.04087 \\
(-0.468) \\
{[.01049}\end{array}\right]$ \\
\hline III.3 & Stone/Ceramics & $\begin{array}{c}.08505 \\
(1.196) \\
{[.01190]}\end{array}$ & $\begin{array}{c}.08897 \\
(1.138) \\
{[.01140]}\end{array}$ & $\begin{array}{c}.04364 \\
(0.603) \\
{[.01310]}\end{array}$ & $\begin{array}{c}.03276 \\
(0.412) \\
{[.00925]}\end{array}$ & $\begin{array}{c}.04303 \\
(0.560) \\
{[.01005]}\end{array}$ & $\begin{array}{c}.10344 \\
(1.162) \\
{[.00948]}\end{array}$ & $\begin{array}{c}.09861 \\
(1.273) \\
{[.01312]}\end{array}$ \\
\hline III. 4 & Metal & $\begin{array}{l}.05705 \\
(5.286) \\
{[.35822]}\end{array}$ & $\begin{array}{c}(.06538 \\
(5.391) \\
{[.33967]}\end{array}$ & $\begin{array}{l}.04879 \\
(4.017) \\
{[.33551]}\end{array}$ & $\begin{array}{c}.05865 \\
(5.231) \\
{[.33796]}\end{array}$ & $\begin{array}{c}.07005 \\
(5.932) \\
{[.31909]}\end{array}$ & $\begin{array}{c}.06294 \\
(4.540) \\
{[.30249]}\end{array}$ & $\begin{array}{c}.08623 \\
(6.201) \\
{[.31496]}\end{array}$ \\
\hline III.5 & Wood/Printing & $\begin{array}{l}-.04059 \\
(-1.077) \\
{[.04220]}\end{array}$ & $\begin{array}{c}.00202 \\
(0.052) \\
{[.04562]}\end{array}$ & $\begin{array}{l}-.06208 \\
(-1.624) \\
{[.04718]}\end{array}$ & $\begin{array}{c}.02719 \\
(0.772) \\
{[.04629]}\end{array}$ & $\begin{array}{l}-.02047 \\
(-0.557) \\
{[.04396]}\end{array}$ & $\begin{array}{l}-.08848 \\
(-2.105) \\
{[.04270]}\end{array}$ & $\left.\begin{array}{c}-.01322 \\
(-0.289 \\
{[.03805}\end{array}\right)$ \\
\hline III. 6 & Textiles/Clothes & $\begin{array}{c}-.03668 \\
(-0.663) \\
{[.01948]}\end{array}$ & $\begin{array}{c}.03572 \\
(0.551) \\
{[.01647]}\end{array}$ & $\begin{array}{c}.00190 \\
(0.032) \\
{[.01965]}\end{array}$ & $\left.\begin{array}{c}-.07790 \\
(-1.254) \\
.01504\end{array}\right]$ & $\left.\begin{array}{l}-.04257 \\
(-0.649 \\
{[.01381}\end{array}\right]$ & $\left.\begin{array}{l}-.09783 \\
(-1.351 \\
.01423\end{array}\right]$ & $\left.\begin{array}{c}-.16988 \\
(-2.188 \\
.01312\end{array}\right)$ \\
\hline III.7 & Food & $\begin{array}{l}-.08303 \\
(-2.163) \\
{[.04004]}\end{array}$ & $\begin{array}{l}-.09804 \\
(-2.446) \\
{[.04309]}\end{array}$ & $\begin{array}{l}-.09017 \\
(-2.103) \\
{[.03669]}\end{array}$ & $\begin{array}{l}-.07076 \\
(-1.520) \\
{[.02662]}\end{array}$ & $\begin{array}{l}-.04524 \\
(-1.094) \\
{[.03391]}\end{array}$ & $\begin{array}{l}-.05432 \\
(-1.145) \\
{[.03321]}\end{array}$ & $\left.\begin{array}{c}-.04203 \\
(-0.784) \\
{[.02755}\end{array}\right]$ \\
\hline IV & Construction & $\begin{array}{l}-.05493 \\
(-2.607) \\
{[.13203]}\end{array}$ & $\begin{array}{l}-.05106 \\
(-2.267) \\
{[.13307]}\end{array}$ & $\begin{array}{c}.00189 \\
(0.084) \\
{[.13106]}\end{array}$ & $\begin{array}{l}-.02465 \\
(-1.213) \\
{[.13657]}\end{array}$ & $\begin{array}{l}-.04265 \\
(-2.069) \\
{[.13693]}\end{array}$ & $\begin{array}{c}.01604 \\
(0.700) \\
{[.13997]}\end{array}$ & $\begin{array}{c}.01684 \\
(0.682) \\
{[.12729]}\end{array}$ \\
\hline $\mathrm{V}$ & Trade & $\left.\begin{array}{c}-.13251 \\
(-3.696 \\
{[.05844}\end{array}\right]$ & $\left.\begin{array}{l}-.11315 \\
(-3.523) \\
{[.07731}\end{array}\right]$ & $\left.\begin{array}{l}-.07736 \\
(-2.311 \\
.07077\end{array}\right]$ & $\left.\begin{array}{c}-.10760 \\
(-3.431 \\
.06828\end{array}\right]$ & $\left.\begin{array}{l}-.13448 \\
(-4.458 \\
{[.07663}\end{array}\right]$ & $\left.\begin{array}{l}-.10063 \\
(-3.448 \\
.09371\end{array}\right]$ & $\left.\begin{array}{c}-.13613 \\
-4.632 \\
.09842\end{array}\right]$ \\
\hline VI & Transportation & $\left.\begin{array}{l}-.06665 \\
(-2.085 \\
.05735\end{array}\right]$ & $\left.\begin{array}{c}-.00171 \\
(-0.043) \\
{[.04435}\end{array}\right]$ & $\left.\begin{array}{l}-.00847 \\
(-0.216 \\
{[.04456}\end{array}\right]$ & $\left.\begin{array}{c}-.04491 \\
(-1.463 \\
.06250\end{array}\right]$ & $\left.\begin{array}{c}-.06982 \\
(-2.218 \\
{[.05904}\end{array}\right]$ & $\left.\begin{array}{c}-.05620 \\
-1.547 \\
.05693\end{array}\right]$ & $\left.\begin{array}{c}-.08300 \\
-2.378 \\
.06430\end{array}\right]$ \\
\hline VII & Banking & $\begin{array}{c}.05314 \\
(1.448) \\
{[.06385]}\end{array}$ & $\begin{array}{c}-.00529 \\
(-0.135) \\
{[.06210]}\end{array}$ & $\begin{array}{l}-.02526 \\
(-0.645) \\
{[.06159]}\end{array}$ & $\begin{array}{c}.03071 \\
(0.834) \\
{[.06018]}\end{array}$ & $\begin{array}{c}.00143 \\
(0.039) \\
{[.06909]}\end{array}$ & $\begin{array}{c}.04206 \\
(1.056) \\
{[.06642]}\end{array}$ & $\left.\begin{array}{c}.00513 \\
(0.123) \\
{[.06430}\end{array}\right]$ \\
\hline VIII & Other Services & $\left.\begin{array}{l}-.13535 \\
(-5.064) \\
{[.08658}\end{array}\right]$ & $\begin{array}{l}-.11918 \\
(-4.030) \\
{[.08491]}\end{array}$ & $\begin{array}{l}-.07740 \\
(-2.823) \\
{[.09698]}\end{array}$ & $\begin{array}{l}-.16673 \\
(-6.755) \\
{[.10185]}\end{array}$ & $\begin{array}{l}-.13759 \\
(-5.592) \\
{[.10301]}\end{array}$ & $\begin{array}{l}-.15358 \\
(-5.647) \\
{[.10676]}\end{array}$ & $\left.\begin{array}{l}-.17977 \\
(-6.307 \\
{[.10367}\end{array}\right]$ \\
\hline IX & Non Profit & $\begin{array}{c}-.10573 \\
(-1.883) \\
{[.01948]}\end{array}$ & $\left.\begin{array}{l}-.17470 \\
(-2.862 \\
.01901\end{array}\right]$ & $\left.\begin{array}{l}-.08404 \\
(-1.439 \\
.02096\end{array}\right]$ & $\left.\begin{array}{l}-.13016 \\
(-1.987 \\
.01388\end{array}\right]$ & $\left.\begin{array}{c}-.07082 \\
(-1.066) \\
{[.01381}\end{array}\right]$ & $\left.\begin{array}{l}-.10293 \\
(-1.347 \\
.01304\end{array}\right]$ & $\left.\begin{array}{c}-.10323 \\
(-1.443 \\
.01574\end{array}\right)$ \\
\hline & $\begin{array}{l}\mathrm{N} \\
\mathrm{F} \\
\text { Prob (F) } \\
\mathrm{R}^{2} \\
\text { Adj-R }{ }^{2} \\
\text { Root MSE } \\
\mathrm{S}_{\beta}^{*} F U L L \\
\mathrm{~S}_{\beta}^{*} R A W\end{array}$ & $\begin{array}{c}924 \\
26.59 \\
0.0000 \\
0.4448 \\
0.4281 \\
.23567 \\
.07802 \\
.09660\end{array}$ & $\begin{array}{c}789 \\
25.40 \\
0.0000 \\
0.4740 \\
0.4553 \\
.23455 \\
.07005 \\
.09162\end{array}$ & $\begin{array}{c}763 \\
22.78 \\
0.0000 \\
0.4556 \\
0.4356 \\
.22928 \\
.04575 \\
.08475\end{array}$ & $\begin{array}{c}864 \\
33.81 \\
0.0000 \\
0.5220 \\
0.5066 \\
.22401 \\
.07923 \\
.10523\end{array}$ & $\begin{array}{c}796 \\
29.95 \\
0.0000 \\
0.5129 \\
0.4958 \\
.21698 \\
.08285 \\
.11359\end{array}$ & $\begin{array}{c}843 \\
25.83 \\
0.0000 \\
0.4611 \\
0.4433 \\
.25115 \\
.07748 \\
.10757\end{array}$ & $\begin{array}{c}762 \\
26.32 \\
0.0000 \\
0.4919 \\
0.4732 \\
.24527 \\
.09539 \\
.11954\end{array}$ \\
\hline
\end{tabular}


Table 8: The German Mikrozensus 89-95

\begin{tabular}{|c|c|c|c|c|c|}
\hline & Industry & 1989 & 1991 & 1993 & 1995 \\
\hline II & Energy/Mining & $\begin{array}{c}.06048 \\
(9.155) \\
{[.03783]}\end{array}$ & $\begin{array}{c}.06460 \\
(8.686) \\
{[.03296]}\end{array}$ & $\begin{array}{c}.06515 \\
(8.675) \\
{[.03219]}\end{array}$ & $\begin{array}{c}.05835 \\
(7.498) \\
{[.03122]}\end{array}$ \\
\hline III.1 & Chemicals & $\left.\begin{array}{l}.07235 \\
(12.178) \\
{[.04839}\end{array}\right]$ & $\left.\begin{array}{l}.07678 \\
(12.172 \\
.04741\end{array}\right]$ & $\left.\begin{array}{l}.08797 \\
(13.484 \\
.04405\end{array}\right]$ & $\left.\begin{array}{l}.07305 \\
(10.025 \\
.03667\end{array}\right]$ \\
\hline III.2 & Plastics & $\begin{array}{c}.01456 \\
(1.503) \\
{[.01767]}\end{array}$ & $\begin{array}{c}.01633 \\
(1.677) \\
{[.01931]}\end{array}$ & $\begin{array}{c}.01671 \\
(1.633) \\
{[.01747]}\end{array}$ & $\left.\begin{array}{c}-.00851 \\
(-0.786) \\
{[.01631}\end{array}\right]$ \\
\hline III.3 & Stone/Ceramics & $\begin{array}{l}-.03325 \\
(-3.688) \\
{[.02063]}\end{array}$ & $\begin{array}{l}-.03327 \\
(-3.218) \\
{[.01736]}\end{array}$ & $\begin{array}{l}-.01979 \\
(-1.909) \\
{[.01724]}\end{array}$ & $\begin{array}{c}-.00194 \\
(-0.198) \\
{[.01992]}\end{array}$ \\
\hline III. 4 & Metal & $\left.\begin{array}{l}.06092 \\
(28.492 \\
.32110\end{array}\right\}$ & $\left.\begin{array}{l}.05781 \\
25.799 \\
.33035\end{array}\right\}$ & $\left.\begin{array}{l}.05301 \\
23.286 \\
.31484\end{array}\right\}$ & $\left.\begin{array}{l}.06049 \\
25.141 \\
.29046\end{array}\right\}$ \\
\hline III.5 & Wood/Printing & $\begin{array}{c}.01546 \\
(2.596) \\
{[.04954]}\end{array}$ & $\begin{array}{c}.02718 \\
(4.327) \\
{[.04968]}\end{array}$ & $\begin{array}{c}.01906 \\
(3.087) \\
{[.05056]}\end{array}$ & $\begin{array}{c}.04707 \\
(7.101) \\
{[.04540]}\end{array}$ \\
\hline III. 6 & Textiles/Clothes & $\begin{array}{l}-.04300 \\
(-3.817) \\
{[.01624]}\end{array}$ & $\begin{array}{l}-.02705 \\
(-2.144) \\
{[.01386]}\end{array}$ & $\begin{array}{l}-.03028 \\
(-2.241) \\
{[.01223]}\end{array}$ & $\begin{array}{l}-.03605 \\
(-2.514) \\
{[.01098]}\end{array}$ \\
\hline III.7 & Food & $\begin{array}{l}-.04072 \\
(-5.177) \\
{[.03146]}\end{array}$ & $\begin{array}{l}-.02834 \\
(-3.356) \\
{[.03085]}\end{array}$ & $\begin{array}{c}-.03687 \\
(-4.245) \\
{[.02937]}\end{array}$ & $\begin{array}{c}-.01114 \\
(-1.259) \\
{[.02955]}\end{array}$ \\
\hline IV & Construction & $\left.\begin{array}{l}-.00200 \\
(-0.499 \\
{[.11566}\end{array}\right]$ & $\begin{array}{c}.01847 \\
(4.449) \\
{[.12089]}\end{array}$ & $\begin{array}{c}.03296 \\
(8.211) \\
{[.12602]}\end{array}$ & $\begin{array}{c}.03081 \\
(7.602) \\
{[.12905]}\end{array}$ \\
\hline $\mathrm{V}$ & Trade & $\begin{array}{c}-.08441 \\
(-20.044) \\
{[.09840]}\end{array}$ & $\begin{array}{c}-.09645 \\
(-20.888) \\
{[.09265]}\end{array}$ & $\begin{array}{c}-.09505 \\
(-21.352 \\
{[.09813]}\end{array}$ & $\begin{array}{c}-.07438 \\
(-19.536) \\
{[.13009]}\end{array}$ \\
\hline VI & Transportation & $\begin{array}{l}-.04073 \\
(-7.571) \\
{[.06359]}\end{array}$ & $\begin{array}{l}-.04207 \\
(-7.347) \\
{[.06292]}\end{array}$ & $\begin{array}{l}-.04213 \\
(-7.538) \\
{[.06559]}\end{array}$ & $\begin{array}{l}-.04658 \\
(-8.121) \\
{[.06525]}\end{array}$ \\
\hline VII & Banking & $\begin{array}{c}.02975 \\
(4.239) \\
{[.04321]}\end{array}$ & $\begin{array}{c}.03477 \\
(4.700) \\
{[.04464]}\end{array}$ & $\begin{array}{c}.05365 \\
(7.354) \\
{[.04428]}\end{array}$ & $\begin{array}{c}.06881 \\
(9.519) \\
{[.04628]}\end{array}$ \\
\hline VIII & Other Services & $\begin{array}{c}-.09250 \\
(-23.239) \\
{[.12370]}\end{array}$ & $\begin{array}{c}-.11417 \\
(-27.281 \\
{[.12270]}\end{array}$ & $\begin{array}{c}-.10421 \\
(-26.307 \\
{[.13267]}\end{array}$ & $\begin{array}{c}-.11765 \\
(-29.186) \\
{[.13786]}\end{array}$ \\
\hline IX & Non Profit & $\begin{array}{c}-.19371 \\
(-16.600) \\
{[.01251]}\end{array}$ & $\begin{array}{c}-.20200 \\
(-17.518) \\
{[.01435]}\end{array}$ & $\begin{array}{c}-.17912 \\
(-16.123) \\
{[.01528]}\end{array}$ & $\begin{array}{c}-.14058 \\
(-10.490 \\
{[.01089}\end{array}$ \\
\hline & $\begin{array}{l}\mathrm{N} \\
\mathrm{K} \\
\mathrm{F} \\
\text { Prob (F) } \\
\text { Adj-R }{ }^{2} \\
\mathrm{~S}_{\beta}^{*} F U L L \\
\mathrm{~S}_{\beta}^{*} R A W\end{array}$ & $\begin{array}{c}51042 \\
37 \\
869.58 \\
0.0000 \\
0.3864 \\
.06366 \\
.08620\end{array}$ & $\begin{array}{c}56272 \\
37 \\
855.67 \\
0.0000 \\
0.3598 \\
.06959 \\
.08592\end{array}$ & $\begin{array}{c}56068 \\
37 \\
867.25 \\
0.0000 \\
0.3637 \\
.06793 \\
.08727\end{array}$ & $\begin{array}{c}54444 \\
37 \\
832.79 \\
0.0000 \\
.32228 \\
.06915 \\
.08661\end{array}$ \\
\hline
\end{tabular}


Table 9: The American PSID 84-89

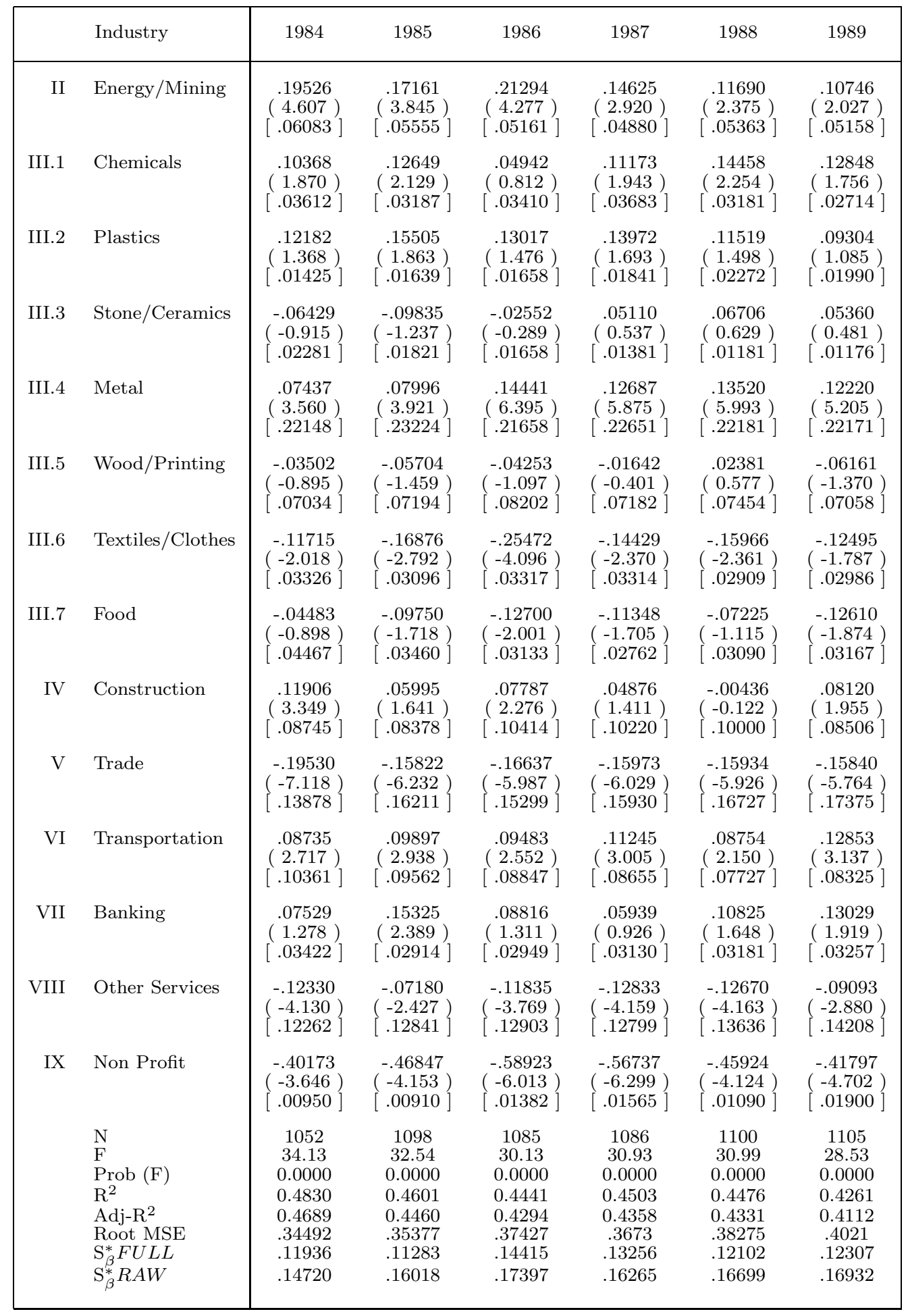


Table 10: The American PSID 90-92 / PANEL

\begin{tabular}{|c|c|c|c|c|c|c|c|}
\hline & Industry & 1990 & 1991 & 1992 & Pooled 84-92 & RE Panel 84-92 & FE Panel 84-92 \\
\hline II & Energy/Mining & $\begin{array}{c}.20438 \\
(4.018) \\
{[.04541]}\end{array}$ & $\begin{array}{c}.11940 \\
(2.143) \\
{[.04450]}\end{array}$ & $\begin{array}{c}.12747 \\
(2.421) \\
{[.05037]}\end{array}$ & $\begin{array}{c}.15684 \\
(9.547) \\
{[.05130]}\end{array}$ & $\begin{array}{c}.08962 \\
(5.231) \\
{[.05130]}\end{array}$ & $\begin{array}{c}.06987 \\
(3.819) \\
{[.05130]}\end{array}$ \\
\hline III.1 & Chemicals & $\begin{array}{l}.22143 \\
(3.275) \\
{[.02620]}\end{array}$ & $\begin{array}{l}.23367 \\
(3.039) \\
{[.02361]}\end{array}$ & $\begin{array}{c}.24384 \\
(3.138) \\
{[.02332]}\end{array}$ & $\begin{array}{c}.14215 \\
(6.590) \\
{[.03006]}\end{array}$ & $\begin{array}{c}.01851 \\
(0.886) \\
{[.03006]}\end{array}$ & $\begin{array}{l}-.02925 \\
(-1.346) \\
{[.03006]}\end{array}$ \\
\hline III. 2 & Plastics & $\begin{array}{c}.04892 \\
(0.687) \\
{[.02358]}\end{array}$ & $\begin{array}{c}.11518 \\
(1.403) \\
{[.02089]}\end{array}$ & $\begin{array}{c}.09520 \\
(1.193) \\
{[.02238]}\end{array}$ & $\begin{array}{c}.10667 \\
(3.954) \\
{[.01950]}\end{array}$ & $\begin{array}{c}.03983 \\
(1.624) \\
{[.01950]}\end{array}$ & $\begin{array}{l}.03452 \\
(1.361) \\
{[.01950]}\end{array}$ \\
\hline III.3 & Stone/Ceramics & $\begin{array}{c}.05911 \\
(0.636) \\
{[.01397]}\end{array}$ & $\begin{array}{l}-.01915 \\
(-0.206) \\
{[.01634]}\end{array}$ & $\begin{array}{c}.03194 \\
(0.258) \\
{[.00932]}\end{array}$ & $\begin{array}{l}-.00445 \\
(-0.144) \\
{[.01493]}\end{array}$ & $\begin{array}{c}.02414 \\
(0.923) \\
{[.01493]}\end{array}$ & $\begin{array}{c}.04687 \\
(1.742) \\
{\left[\begin{array}{l}.01493]\end{array}\right]}\end{array}$ \\
\hline III. 4 & Metal & $\begin{array}{c}.11110 \\
(5.349) \\
{[.22707]}\end{array}$ & $\begin{array}{l}.10284 \\
(4.162) \\
{[.19981]}\end{array}$ & $\begin{array}{c}.10277 \\
(4.223) \\
{[.20335]}\end{array}$ & $\left.\begin{array}{l}.11122 \\
(15.057) \\
.21901\end{array}\right\}$ & $\begin{array}{c}.05303 \\
(7.198) \\
{[.21901]}\end{array}$ & $\begin{array}{c}.03975 \\
(5.050) \\
{[.21901]}\end{array}$ \\
\hline III. 5 & Wood/Printing & $\begin{array}{l}-.09608 \\
(-2.381) \\
{[.07161]}\end{array}$ & $\begin{array}{c}-.05597 \\
(-1.219) \\
{[.06539]}\end{array}$ & $\begin{array}{c}-.05581 \\
(-1.301) \\
{[.07369]}\end{array}$ & $\begin{array}{l}-.04257 \\
(-3.099) \\
{[.07242]}\end{array}$ & $\begin{array}{l}-.06942 \\
(-4.702) \\
{[.07242]}\end{array}$ & $\begin{array}{l}-.05349 \\
(-3.317) \\
{[.07242]}\end{array}$ \\
\hline III. 6 & Textiles/Clothes & $\begin{array}{l}-.16269 \\
(-2.328) \\
{[.02445]}\end{array}$ & $\begin{array}{l}-.15708 \\
(-2.394) \\
{[.03269]}\end{array}$ & $\begin{array}{c}-.11609 \\
(-1.422) \\
{[.02145]}\end{array}$ & $\begin{array}{l}-.16064 \\
(-7.379) \\
{[.02976]}\end{array}$ & $\begin{array}{l}-.03826 \\
(-2.086) \\
{[.02976]}\end{array}$ & $\begin{array}{c}-.00372 \\
(-0.198) \\
{[.02976]}\end{array}$ \\
\hline III.7 & Food & $\begin{array}{l}-.04274 \\
(-0.659) \\
{[.02794]}\end{array}$ & $\begin{array}{c}-.08728 \\
(-1.378) \\
{[.03451]}\end{array}$ & $\begin{array}{c}-.09207 \\
(-1.445) \\
{[.03451]}\end{array}$ & $\begin{array}{l}-.08622 \\
(-4.199) \\
{[.03301]}\end{array}$ & $\left.\begin{array}{l}-.05020 \\
(-2.501) \\
{[.03301}\end{array}\right]$ & $\begin{array}{l}-.02520 \\
(-1.161) \\
{[.03301]}\end{array}$ \\
\hline IV & Construction & $\begin{array}{c}.08249 \\
(2.372) \\
{[.09519]}\end{array}$ & $\begin{array}{c}.09966 \\
(2.617) \\
{[.09355]}\end{array}$ & $\begin{array}{c}.11982 \\
(3.247) \\
{[.10261]}\end{array}$ & $\begin{array}{c}.07476 \\
(6.206) \\
{[.09488]}\end{array}$ & $\begin{array}{c}.03758 \\
(3.510) \\
{[.09488]}\end{array}$ & $\begin{array}{c}.03998 \\
(3.539) \\
{[.09488]}\end{array}$ \\
\hline $\mathrm{V}$ & Trade & $\begin{array}{l}-.15693 \\
(-6.297) \\
{[.17379]}\end{array}$ & $\begin{array}{l}-.17496 \\
(-6.623) \\
{[.18256]}\end{array}$ & $\begin{array}{l}-.15820 \\
(-5.665) \\
{[.16697]}\end{array}$ & $\begin{array}{c}-.16553 \\
(-18.684) \\
{[.16436]}\end{array}$ & $\begin{array}{c}-.08939 \\
(-11.467) \\
{[.16436]}\end{array}$ & $\begin{array}{l}-.07438 \\
(-9.140) \\
{[.16436]}\end{array}$ \\
\hline VI & Transportation & $\begin{array}{l}.13752 \\
(3.512) \\
{[.07510]}\end{array}$ & $\begin{array}{c}.10645 \\
(2.593) \\
{[.07992]}\end{array}$ & $\begin{array}{c}.05455 \\
(1.323) \\
{[.08022]}\end{array}$ & $\begin{array}{c}.10367 \\
(8.227) \\
{[.08543]}\end{array}$ & $\begin{array}{c}.08242 \\
(6.126) \\
{[.08543]}\end{array}$ & $\begin{array}{c}.07417 \\
(5.075) \\
{[.08543]}\end{array}$ \\
\hline VII & Banking & $\begin{array}{c}.04532 \\
(0.736) \\
{[.03231]}\end{array}$ & $\begin{array}{c}.07745 \\
(1.066) \\
{[.02724]}\end{array}$ & $\begin{array}{c}.16066 \\
(2.546) \\
{[.03638]}\end{array}$ & $\begin{array}{c}.10120 \\
(4.707) \\
{[.03159]}\end{array}$ & $\begin{array}{c}.00526 \\
(0.212) \\
{[.03159]}\end{array}$ & $\begin{array}{l}-.06070 \\
(-2.192) \\
{[.03159]}\end{array}$ \\
\hline VIII & Other Services & $\left.\begin{array}{l}-.09685 \\
(-3.462 \\
{[.14672}\end{array}\right]$ & $\left.\begin{array}{c}-.02084 \\
(-0.724) \\
{[.16348}\end{array}\right]$ & $\left.\begin{array}{c}-.08601 \\
(-2.923 \\
{[.15764}\end{array}\right]$ & $\left.\begin{array}{l}-.09428 \\
(-9.514 \\
.13947\end{array}\right]$ & $\left.\begin{array}{l}-.02967 \\
(-3.434 \\
.13947\end{array}\right)$ & $\left.\begin{array}{c}-.0214 \\
(-2.381 \\
.13947\end{array}\right]$ \\
\hline IX & Non Profit & $\left.\begin{array}{l}-.50612 \\
(-5.894 \\
.01659\end{array}\right)$ & $\left.\begin{array}{l}-.40534 \\
(-4.183) \\
{[.01544}\end{array}\right]$ & $\left.\begin{array}{l}-.46244 \\
(-5.108) \\
{[.01772}\end{array}\right]$ & $\left.\begin{array}{c}-.47625 \\
(-14.930) \\
{[.01422]}\end{array}\right)$ & $\left.\begin{array}{l}-.14238 \\
(-4.836 \\
.01422\end{array}\right\}$ & $\left.\begin{array}{c}-.06760 \\
(-2.196) \\
{[.01422}\end{array}\right]$ \\
\hline & $\begin{array}{l}\mathrm{N} \\
\mathrm{F} \\
\text { Prob (F) } \\
\mathrm{R}^{2} \\
\text { Adj-R }{ }^{2} \\
\text { Root MSE } \\
\mathrm{S}_{\beta}^{*} F U L L \\
\mathrm{~S}_{\beta}^{*} R A W\end{array}$ & $\begin{array}{c}1145 \\
35.87 \\
0.0000 \\
0.4737 \\
0.4605 \\
.3698 \\
.13365 \\
.16771\end{array}$ & $\begin{array}{c}1101 \\
33.87 \\
0.0000 \\
0.4694 \\
0.4556 \\
.3934 \\
.11776 \\
.16530\end{array}$ & $\begin{array}{c}1072 \\
31.30 \\
0.0000 \\
0.4566 \\
0.4420 \\
.39024 \\
.12339 \\
.16639\end{array}$ & $\begin{array}{c}9844 \\
223.76 \\
0.0000 \\
0.4510 \\
0.4490 \\
.37452 \\
.12843 \\
.16765\end{array}$ & $\begin{array}{c}9844 \\
- \\
- \\
0.3999 \\
- \\
- \\
.06176 \\
.06229\end{array}$ & $\begin{array}{c}9844 \\
10.01 \\
0.0000 \\
0.0410 \\
- \\
- \\
- \\
.04980\end{array}$ \\
\hline
\end{tabular}


Table 11: The American CPS 84-89

\begin{tabular}{|c|c|c|c|c|c|c|c|}
\hline & & 1984 & 1985 & 1986 & 1987 & 1988 & 1989 \\
\hline II & Energy/Mining & $\left.\begin{array}{l}.16277 \\
15.619 \\
.02914\end{array}\right\}$ & $\left.\begin{array}{l}.14600 \\
13.912 \\
.02751\end{array}\right\}$ & $\left.\begin{array}{l}.15588 \\
14.598 \\
.02705\end{array}\right\}$ & $\left.\begin{array}{l}.17309 \\
16.341 \\
.02763\end{array}\right\}$ & $\left.\begin{array}{l}.17509 \\
16.682 \\
.02826\end{array}\right\}$ & $\left.\begin{array}{l}.15743 \\
14.160 \\
.02830\end{array}\right)$ \\
\hline III.1 & Chemicals & $\left.\begin{array}{l}.17456 \\
(20.977 \\
{[.04468}\end{array}\right]$ & $\left.\begin{array}{l}.18497 \\
(22.507 \\
.04410\end{array}\right]$ & $\left.\begin{array}{l}.18593 \\
(21.566 \\
{[.04093}\end{array}\right]$ & $\left.\begin{array}{c}.16878 \\
(19.093 \\
{[.03912}\end{array}\right]$ & $\left.\begin{array}{l}.16741 \\
(18.298 \\
{[.03676}\end{array}\right]$ & $\left.\begin{array}{l}.17944 \\
(18.393 \\
{[.03635}\end{array}\right]$ \\
\hline III.2 & Plastics & $\begin{array}{c}.08748 \\
(7.022) \\
{[.02039]}\end{array}$ & $\begin{array}{c}.05997 \\
(4.909) \\
{[.02026]}\end{array}$ & $\begin{array}{c}.05388 \\
(4.382) \\
{[.02036]}\end{array}$ & $\begin{array}{c}.06970 \\
(5.694) \\
{[.02064]}\end{array}$ & $\begin{array}{c}.06709 \\
(5.654) \\
{[.02208]}\end{array}$ & $\begin{array}{c}.09087 \\
(7.228) \\
{[.02211]}\end{array}$ \\
\hline III.3 & Stone/Ceramics & $\begin{array}{l}-.02108 \\
(-1.251) \\
{[.01117]}\end{array}$ & $\begin{array}{l}-.00209 \\
(-0.126) \\
{[.01103]}\end{array}$ & $\begin{array}{c}.00881 \\
(0.547) \\
{[.01189]}\end{array}$ & $\begin{array}{c}.00649 \\
(0.394) \\
{[.01140]}\end{array}$ & $\begin{array}{c}.00483 \\
(0.291) \\
{[.01125]}\end{array}$ & $\begin{array}{c}.00085 \\
(0.051) \\
{[.01262]}\end{array}$ \\
\hline III.4 & Metal & $\left.\begin{array}{c}.07255 \\
19.270 \\
.20503\end{array}\right\}$ & $\left.\begin{array}{c}.08430 \\
(22.752 \\
.20289\end{array}\right\}$ & $\left.\begin{array}{l}.07940 \\
21.091 \\
.20130\end{array}\right\}$ & $\left.\begin{array}{l}.07626 \\
19.647 \\
.19277\end{array}\right\}$ & $\left.\begin{array}{c}.07457 \\
19.094 \\
.19042\end{array}\right\}$ & $\left.\begin{array}{c}.07469 \\
17.908 \\
.18673\end{array}\right\}$ \\
\hline III.5 & Wood/Printing & $\begin{array}{l}-.01345 \\
(-1.864) \\
{[.06012]}\end{array}$ & $\begin{array}{l}-.01282 \\
(-1.776) \\
{[.05758]}\end{array}$ & $\begin{array}{c}.00051 \\
(0.071) \\
{[.05849]}\end{array}$ & $\begin{array}{c}.01137 \\
(1.594) \\
{[.06038]}\end{array}$ & $\begin{array}{c}.01472 \\
(2.052) \\
{[.05991]}\end{array}$ & $\begin{array}{c}.00759 \\
(1.001) \\
{[.06012]}\end{array}$ \\
\hline III. 6 & Textiles/Clothes & $\begin{array}{l}-.10076 \\
(-7.113) \\
{[.01600]}\end{array}$ & $\begin{array}{l}-.08347 \\
(-6.107) \\
{[.01644]}\end{array}$ & $\begin{array}{l}-.08434 \\
(-6.015) \\
{[.01588]}\end{array}$ & $\begin{array}{l}-.12629 \\
(-8.779) \\
{[.01522]}\end{array}$ & $\begin{array}{l}-.10796 \\
(-7.436) \\
{[.01499]}\end{array}$ & $\begin{array}{c}-.09093 \\
(-5.769) \\
{[.01430]}\end{array}$ \\
\hline III.7 & Food & $\begin{array}{l}-.03162 \\
(-3.112) \\
{[.03042]}\end{array}$ & $\begin{array}{l}-.03857 \\
(-3.804) \\
{[.02931]}\end{array}$ & $\begin{array}{l}-.03573 \\
(-3.519) \\
{[.02970]}\end{array}$ & $\begin{array}{c}-.05279 \\
(-5.010) \\
{[.02775]}\end{array}$ & $\begin{array}{l}-.04588 \\
(-4.364) \\
{[.02794]}\end{array}$ & $\begin{array}{l}-.04924 \\
(-4.551) \\
{[.02964]}\end{array}$ \\
\hline IV & Construction & $\left.\begin{array}{l}.07617 \\
(12.962 \\
{[.09481}\end{array}\right]$ & $\left.\begin{array}{l}.06374 \\
(11.266 \\
{[.09802}\end{array}\right]$ & $\left.\begin{array}{l}.06371 \\
(11.144 \\
{[.09864}\end{array}\right]$ & $\left.\begin{array}{c}.07280 \\
(12.734 \\
{[.09883}\end{array}\right]$ & $\left.\begin{array}{c}.06953 \\
(12.206 \\
{[.09986}\end{array}\right]$ & $\left.\begin{array}{l}.07842 \\
(13.142 \\
.10271\end{array}\right]$ \\
\hline $\mathrm{V}$ & Trade & $\begin{array}{c}-.13703 \\
(-31.961) \\
{[.19040]}\end{array}$ & $\begin{array}{c}-.13247 \\
(-31.629) \\
{[.19215]}\end{array}$ & $\begin{array}{c}-.13110 \\
(-30.952) \\
{[.19071]}\end{array}$ & $\begin{array}{c}-.12189 \\
(-29.263) \\
{[.19661]}\end{array}$ & $\begin{array}{c}-.12565 \\
(-30.082) \\
{[.19511]}\end{array}$ & $\begin{array}{c}-.13788 \\
(-31.136) \\
{[.19435]}\end{array}$ \\
\hline VI & Transportation & $\left.\begin{array}{c}.07933 \\
(13.024) \\
{[.08929}\end{array}\right]$ & $\left.\begin{array}{l}.07072 \\
(11.892 \\
{[.08989}\end{array}\right]$ & $\left.\begin{array}{l}.07030 \\
(11.512 \\
{[.08646}\end{array}\right]$ & $\begin{array}{c}.05401 \\
(8.784) \\
{\left[\begin{array}{l}.08629\end{array}\right]}\end{array}$ & $\begin{array}{c}.05508 \\
(8.953) \\
{[.08694]}\end{array}$ & $\begin{array}{c}.04853 \\
(7.354) \\
{[.08437]}\end{array}$ \\
\hline VII & Banking & $\begin{array}{c}.05756 \\
(7.709) \\
{[.05968]}\end{array}$ & $\begin{array}{c}.04909 \\
(6.669) \\
{[.05872]}\end{array}$ & $\begin{array}{c}.05972 \\
(8.215) \\
{[.06085]}\end{array}$ & $\begin{array}{c}.05364 \\
(7.438) \\
{[.06231]}\end{array}$ & $\begin{array}{c}.05356 \\
(7.305) \\
{[.06042]}\end{array}$ & $\left.\begin{array}{l}.08785 \\
(11.247 \\
{[.06000}\end{array}\right]$ \\
\hline VIII & Other Services & $\begin{array}{c}-.08235 \\
(-16.934) \\
{[.13477]}\end{array}$ & $\begin{array}{c}-.08172 \\
(-17.478) \\
{[.13885]}\end{array}$ & $\begin{array}{c}-.08099 \\
(-17.418) \\
{[.14471]}\end{array}$ & $\begin{array}{c}-.06939 \\
(-15.032) \\
{[.14695]}\end{array}$ & $\begin{array}{c}-.06249 \\
(-13.714) \\
{[.15172]}\end{array}$ & $\begin{array}{c}-.05872 \\
(-12.262 \\
{[.15400]}\end{array}$ \\
\hline IX & Non Profit & $\begin{array}{c}-.43679 \\
(-28.566) \\
{[.01404]}\end{array}$ & $\begin{array}{c}-.44833 \\
(-29.077) \\
{[.01319]}\end{array}$ & $\begin{array}{l}-.45611 \\
(-29.076) \\
{[.01296]}\end{array}$ & $\begin{array}{c}-.42287 \\
(-27.932 \\
{[.01403]}\end{array}$ & $\begin{array}{l}-.40578 \\
(-26.996) \\
{[.01427]}\end{array}$ & $\begin{array}{c}-.43440 \\
(-27.332 \\
{[.01432]}\end{array}$ \\
\hline & $\mathrm{N}$ & 47620 & 48956 & 48275 & 48669 & 47085 & 48298 \\
\hline & $\mathrm{F}$ & 650.30 & 727.15 & 727.80 & 719.13 & 704.91 & 722.02 \\
\hline & Prob (F) & 0.0000 & 0.0000 & 0.0000 & 0.0000 & 0.0000 & 0.0000 \\
\hline & $\mathrm{R}^{2}$ & 0.3172 & 0.3357 & 0.3390 & 0.3346 & 0.3375 & 0.3372 \\
\hline & Adj-R ${ }^{2}$ & 0.3168 & 0.3353 & 0.3386 & 0.3341 & 0.3370 & 0.3367 \\
\hline & $\begin{array}{l}\text { Root MSE } \\
\mathrm{S}_{\beta}^{*} F U L L\end{array}$ & $\begin{array}{l}.38963 \\
.10960\end{array}$ & $\begin{array}{l}.38647 \\
.10805\end{array}$ & $\begin{array}{l}.38704 \\
.10714\end{array}$ & $\begin{array}{l}.38964 \\
.10267\end{array}$ & $\begin{array}{l}.38427 \\
.10100\end{array}$ & $\begin{array}{l}.41251 \\
.10707\end{array}$ \\
\hline & $\mathrm{S}_{\beta}^{*} R A W$ & .12701 & .12757 & .12742 & .12095 & .12012 & .12935 \\
\hline
\end{tabular}


Table 12: The American CPS 90-96

\begin{tabular}{|c|c|c|c|c|c|c|c|c|}
\hline & & 1990 & 1991 & 1992 & 1993 & 1994 & 1995 & 1996 \\
\hline II & Energy/Mining & $\left.\begin{array}{c}.16196 \\
14.974 \\
.02867\end{array}\right\}$ & $\left.\begin{array}{l}.16915 \\
15.516 \\
.02942\end{array}\right\}$ & $\begin{array}{c}.09824 \\
(4.079) \\
{[.00620]}\end{array}$ & $\begin{array}{c}.10845 \\
(4.510) \\
{[.00645]}\end{array}$ & $\begin{array}{c}.09019 \\
(3.189) \\
{[.00642]}\end{array}$ & $\begin{array}{c}.03757 \\
(1.366) \\
{[.00702]}\end{array}$ & $\begin{array}{c}.11178 \\
(3.756) \\
{[.00640]}\end{array}$ \\
\hline III.1 & Chemicals & $\left.\begin{array}{l}.17448 \\
(17.823 \\
{[.03459}\end{array}\right]$ & $\left.\begin{array}{l}.16267 \\
(16.461 \\
.03533\end{array}\right]$ & $\left.\begin{array}{l}.17930 \\
(17.415) \\
{[.03343}\end{array}\right]$ & $\left.\begin{array}{l}.18180 \\
(16.820 \\
{[.03156}\end{array}\right)$ & $\left.\begin{array}{l}.13543 \\
(10.773 \\
{[.03205}\end{array}\right)$ & $\left.\begin{array}{c}.16106 \\
12.189 \\
.03005\end{array}\right]$ & $\left.\begin{array}{l}.16239 \\
(11.853 \\
{[.02985}\end{array}\right]$ \\
\hline III.2 & Plastics & $\begin{array}{c}.05530 \\
(4.259) \\
{[.01988]}\end{array}$ & $\begin{array}{c}.07359 \\
(5.785) \\
{[.02155]}\end{array}$ & $\begin{array}{c}.08464 \\
(6.640) \\
{[.02197]}\end{array}$ & $\begin{array}{c}.07094 \\
(5.459) \\
{[.02194]}\end{array}$ & $\begin{array}{c}.03722 \\
(2.483) \\
{[.02273]}\end{array}$ & $\begin{array}{c}.04937 \\
(3.286) \\
{[.02334]}\end{array}$ & $\begin{array}{c}.07692 \\
(4.902) \\
{[.02292]}\end{array}$ \\
\hline III.3 & Stone/Ceramics & $\begin{array}{c}-.00652 \\
(-0.392 \\
{[.01208]}\end{array}$ & $\begin{array}{c}.01120 \\
(0.620) \\
{[.01073]}\end{array}$ & $\begin{array}{c}.01303 \\
(0.710) \\
{[.01068]}\end{array}$ & $\begin{array}{c}.01479 \\
(0.764) \\
{[.00994]}\end{array}$ & $\begin{array}{l}-.02135 \\
(-0.928) \\
{[.00970]}\end{array}$ & $\begin{array}{c}.01581 \\
(0.704) \\
{[.01048]}\end{array}$ & $\begin{array}{c}.00128 \\
(0.055) \\
{[.01054]}\end{array}$ \\
\hline III. 4 & Metal & $\left.\begin{array}{c}.07276 \\
17.544 \\
.18339\end{array}\right\}$ & $\left.\begin{array}{c}.07839 \\
18.374 \\
.18094\end{array}\right\}$ & $\left.\begin{array}{l}.07344 \\
16.654 \\
.17456\end{array}\right\}$ & $\left.\begin{array}{l}.07455 \\
16.407 \\
.17149\end{array}\right\}$ & $\left.\begin{array}{c}.06986 \\
13.512 \\
.18011\end{array}\right\}$ & $\left.\begin{array}{l}.06405 \\
12.012 \\
.17528\end{array}\right\}$ & $\left\{\begin{array}{l}.05963 \\
10.597 \\
.17022\end{array}\right\}$ \\
\hline III.5 & Wood/Printing & $\begin{array}{c}.01164 \\
(1.557) \\
{[.05950]}\end{array}$ & $\begin{array}{c}.00303 \\
(0.392) \\
{[.05799]}\end{array}$ & $\begin{array}{c}.00616 \\
(0.782) \\
{[.05741]}\end{array}$ & $\begin{array}{c}.01267 \\
(1.582) \\
{[.05763]}\end{array}$ & $\begin{array}{c}.00883 \\
(0.956) \\
{[.05966]}\end{array}$ & $\begin{array}{c}.00961 \\
(1.002) \\
{[.05683]}\end{array}$ & $\begin{array}{c}.01153 \\
(1.178) \\
{[.05871]}\end{array}$ \\
\hline III.6 & Textiles/Clothes & $\begin{array}{l}-.07622 \\
(-4.853) \\
{[.01386]}\end{array}$ & $\begin{array}{l}-.08150 \\
(-5.081 \\
{[.01376]}\end{array}$ & $\begin{array}{l}-.06526 \\
(-3.988) \\
{[.01354]}\end{array}$ & $\begin{array}{l}-.06156 \\
(-3.730) \\
{[.01380]}\end{array}$ & $\begin{array}{l}-.09505 \\
(-5.014) \\
{[.01440]}\end{array}$ & $\begin{array}{l}-.06114 \\
(-3.109) \\
{[.01380]}\end{array}$ & $\begin{array}{l}-.06905 \\
(-3.164) \\
{[.01199]}\end{array}$ \\
\hline III.7 & Food & $\begin{array}{c}-.07571 \\
(-6.982) \\
{[.02837]}\end{array}$ & $\begin{array}{l}-.04677 \\
(-4.176) \\
{[.02769]}\end{array}$ & $\begin{array}{c}-.05047 \\
(-4.507 \\
{[.02837]}\end{array}$ & $\begin{array}{l}-.03456 \\
(-2.994) \\
{[.02772]}\end{array}$ & $\begin{array}{c}-.02747 \\
(-1.971) \\
{[.02615]}\end{array}$ & $\begin{array}{l}-.04310 \\
(-3.030) \\
{[.02596]}\end{array}$ & $\begin{array}{c}-.04798 \\
(-3.287) \\
{[.02635]}\end{array}$ \\
\hline IV & Construction & $\left.\begin{array}{c}.07721 \\
(13.225 \\
{[.10336}\end{array}\right]$ & $\left.\begin{array}{l}.07518 \\
(12.150 \\
.09537\end{array}\right)$ & $\left.\begin{array}{c}.06838 \\
(10.767 \\
{[.09268}\end{array}\right]$ & $\begin{array}{c}.05775 \\
(9.118) \\
{[.09690]}\end{array}$ & $\begin{array}{c}.05249 \\
(7.065) \\
{[.09706]}\end{array}$ & $\begin{array}{c}.04435 \\
(5.952) \\
{[.09949]}\end{array}$ & $\begin{array}{c}.04384 \\
(5.785) \\
{[.10318]}\end{array}$ \\
\hline $\mathrm{V}$ & Trade & $\begin{array}{c}-.12883 \\
(-30.162 \\
{[.19797]}\end{array}$ & $\begin{array}{c}-.13296 \\
(-30.525) \\
{[.19983]}\end{array}$ & $\begin{array}{c}-.13108 \\
(-29.962) \\
{[.20276]}\end{array}$ & $\begin{array}{l}-.12528 \\
(-28.389 \\
{[.20526]}\end{array}$ & $\begin{array}{l}-.12443 \\
(-24.560) \\
{[.21483]}\end{array}$ & $\begin{array}{c}-.11480 \\
(-22.689) \\
{[.21810]}\end{array}$ & $\begin{array}{c}-.11217 \\
(-21.446) \\
{[.22035]}\end{array}$ \\
\hline VI & Transportation & $\begin{array}{c}.05271 \\
(8.035) \\
{[.08284]}\end{array}$ & $\begin{array}{c}.04807 \\
(7.281) \\
{[.08476]}\end{array}$ & $\left.\begin{array}{l}.07552 \\
(13.099 \\
{[.11027}\end{array}\right)$ & $\left.\begin{array}{c}.07969 \\
(13.381 \\
.10816\end{array}\right]$ & $\begin{array}{c}.06384 \\
(9.070) \\
{[.10562]}\end{array}$ & $\begin{array}{c}.06045 \\
(8.363) \\
{[.10259]}\end{array}$ & $\begin{array}{c}.05183 \\
(6.890) \\
{[.10172]}\end{array}$ \\
\hline VII & Banking & $\left.\begin{array}{l}.08368 \\
(11.097 \\
.06169\end{array}\right]$ & $\begin{array}{c}.07546 \\
(9.700) \\
{[.06080]}\end{array}$ & $\left.\begin{array}{c}.09747 \\
(12.340 \\
{[.05960}\end{array}\right]$ & $\left.\begin{array}{c}.10023 \\
(12.471 \\
.05952\end{array}\right)$ & $\begin{array}{c}.07197 \\
(7.702) \\
{[.06055]}\end{array}$ & $\begin{array}{c}.08695 \\
(9.185) \\
{[.06045]}\end{array}$ & $\begin{array}{c}.09209 \\
(9.333) \\
{[.05958]}\end{array}$ \\
\hline VIII & Other Services & $\begin{array}{c}-.05367 \\
(-11.761 \\
{[.16025]}\end{array}$ & $\begin{array}{c}-.04725 \\
(-10.408) \\
{[.16794]}\end{array}$ & $\left.\begin{array}{l}-.04466 \\
(-9.869) \\
{[.17362}\end{array}\right]$ & $\begin{array}{l}-.05094 \\
(-11.153) \\
{[.17453]}\end{array}$ & $\left.\begin{array}{l}-.02922 \\
(-5.310 \\
{[.16615}\end{array}\right]$ & $\left.\begin{array}{c}-.03487 \\
(-6.398 \\
.17261\end{array}\right]$ & $\left.\begin{array}{c}-.03280 \\
(-5.848) \\
{[.17506}\end{array}\right]$ \\
\hline IX & Non Profit & $\begin{array}{c}-.44011 \\
(-27.493) \\
{[.01348]}\end{array}$ & $\begin{array}{l}-.41019 \\
(-25.418) \\
{[.01384]}\end{array}$ & $\begin{array}{c}-.37754 \\
(-23.913) \\
{[.01484]}\end{array}$ & $\begin{array}{c}-.36078 \\
(-22.577) \\
{[.01503]}\end{array}$ & $\begin{array}{l}-.26406 \\
(-7.807) \\
{[.00451]}\end{array}$ & $\begin{array}{l}-.26633 \\
(-7.227) \\
{[.00393]}\end{array}$ & $\begin{array}{l}-.29469 \\
(-6.827) \\
{[.00305]}\end{array}$ \\
\hline & $\begin{array}{l}\mathrm{N} \\
\mathrm{F} \\
\text { Prob (F) } \\
\mathrm{R}^{2} \\
\text { Adj-R } \\
\text { Root MSE } \\
\mathrm{S}_{\beta}^{*} F U L L \\
\mathrm{~S}_{\beta}^{*} R A W\end{array}$ & $\begin{array}{l}50638 \\
797.11 \\
0.0000 \\
0.3488 \\
0.3483 \\
.41358 \\
.10334 \\
.12918\end{array}$ & $\begin{array}{l}48535 \\
762.69 \\
0.0000 \\
0.3484 \\
0.3479 \\
.41303 \\
.10210 \\
.12892\end{array}$ & $\begin{array}{l}47828 \\
748.78 \\
0.0000 \\
0.3475 \\
0.3471 \\
.41527 \\
.09945 \\
.12794\end{array}$ & $\begin{array}{l}47075 \\
703.61 \\
0.0000 \\
0.3371 \\
0.3366 \\
.41953 \\
.09730 \\
.12305\end{array}$ & $\begin{array}{l}38314 \\
504.30 \\
0.0000 \\
0.3094 \\
0.3087 \\
.44405 \\
.08020 \\
.11896\end{array}$ & $\begin{array}{l}38161 \\
486.97 \\
0.0000 \\
0.3028 \\
0.3022 \\
.45042 \\
.07739 \\
.11548\end{array}$ & $\begin{array}{l}34336 \\
459.85 \\
0.0000 \\
0.3131 \\
0.3124 \\
.44152 \\
.07653 \\
.11584\end{array}$ \\
\hline
\end{tabular}




\section{Author's Affiliations}

John P. Haisken-DeNew The German Institute for Economic Research (DIW-Berlin) and IZABonn.

jhaiskendenew@diw-berlin.de

TEL: +49-30-89789-461.

FAX:+49-30-89789-200.

Christoph M. Schmidt AWI (University of Heidelberg), CEPR London and IZA-Bonn.

christoph.schmidt@urz. uni-heidelberg. de

TEL: +49-89-2180-2128.

FAX: +49-89-33 6392.

\section{Acknowledgements}

This paper celebrates Jascha Pieter Haisken-DeNew, born September 1, 1997 in Berlin, Germany. The authors wish to thank Tom Crossley, Ira Gang, Franque Grimard, Dan Hamermesh, Peter Kuhn, Thomas Lemieux, Dave Richardson, Chuck Romeo, Bernhard Schimpl-Neimanns, Michael Veall, Frank Vella, Lars Vilhuber and numerous other seminar participants at McGill U (Montreal), McMaster U (Hamilton), Rutgers U (NJ), Syracuse U and York U (Toronto) for their valuable suggestions and comments, while Haisken-DeNew was visiting Syracuse University from Oct 1, 1997 to Mar 31, 1998. 